\title{
DEATH, WOMEN, AND POWER: THEME AND STRUCTURE IN REICNE FOTHAID CANAINNE
}

\author{
KRISTEN MILLS \\ University of Oslo
}

\begin{abstract}
This study is a thematic analysis of two understudied Old Irish texts, a poem entitled Reicne Fothaid Canainne and a short prose narrative, describing the death of Fothad Canainne, a leader of a Connacht fian, who, after being killed in battle by Ailill mac Éogain, his rival in love and war, posthumously recites the Reicne to Ailill's wife in his grave-mound. These texts are the most important extant sources for the figure of Fothad Canainne, and give insight into the early Fenian tradition. A Middle Irish prose narrative that expands on the Old Irish prose text is also briefly considered.
\end{abstract}

\section{INTRODUCTION}

The texts known today under the editorial title Reicne Fothaid Canainne consist of an Old Irish poem, a Middle Irish prose narrative that ends with the first line of the poem, and an Old Irish prose narrative, that summarises the events leading up to the genesis of the poem and ends with the first verse of the poem. ${ }^{1}$ The prose narratives and the poem recount the death and afterlife of the legendary warrior Fothad Canainne, the rigféinnid ('chief' [literally 'royal féinnid', see below]) of the Connacht fian, who was slain in a battle by Ailill mac Éogain, ${ }^{2}$ chief of a rival fian in Munster. ${ }^{3}$ Based on linguistic criteria, Kuno Meyer dates the poem to either the eighth century or the late ninth/early tenth century, making it one of the earliest surviving Fenian texts. ${ }^{4}$ Outside of these texts, Fothad Canainne appears only sporadically in medieval Irish literature, although there is evidence that he was once the subject of a sizeable body of material, before his traditional enemy Finn mac Cumaill came to dominate Fenian

- I am deeply indebted to the anonymous peer reviewer for many helpful insights, as well as to the editors of Ériu, whose observations, comments and suggestions have improved this article immensely. I am also very grateful to Richard Cole and Ann Dooley, who patiently read and commented on numerous early drafts of this study.

${ }^{1}$ The Middle Irish prose text and the Old Irish poem are edited together as Reicne Fothaid Canainne in Kuno Meyer (ed. and trans.), Fianaigecht: being a collection of hitherto inedited Irish poems and tales relating to Finn and his Fiana, with an English translation (Todd Lecture Series 16; Dublin, 1910; repr. 1937, 1993), 1-17. David Greene and Frank O'Connor edited and translated selected verses from the poem as 'The dead lover', in David Greene and Frank O'Connor (eds), A golden treasury of Irish poetry, A.D. 600 to 1200 (London, 1967), 86-92. The Old Irish prose narrative is edited and translated by Vernam Hull, in 'The death of Fothath Cananne', ZCP 20 (1936), 400-04. Flann Bec.

${ }^{2}$ This is the name in the Old Irish texts; in the Middle Irish prose text Fothad's rival is named Ailill

${ }^{3}$ The most recent treatment of the fian and similar warrior societies in early Ireland and among the continental Celts is Kim McCone's 'The Celtic and Indo-European origins of the Fían', in Sharon J. Arbuthnot and Geraldine Parsons (eds), The Gaelic Finn tradition (Dublin, 2012), 14-30.

${ }^{4}$ Meyer, Reicne, xix, 1. For the most recent discussions of dating the corpus, see Kevin Murray, 'Interpreting the evidence: problems with dating the early Fianaigecht', in The Gaelic Finn tradition, 31-49; and Kevin Murray, The early Finn Cycle (Dublin, 2017), 130-39. 
tradition during the twelfth-century literary revival of Fenian material. ${ }^{5}$ The church in Ireland took a particular dislike to the fian in the early medieval period, portraying fiana as violent, diabolical, and inimical to Christianity. Only after its decline as an actual social institution did the fian flourish in the textual record. ${ }^{6}$ Acallam na Senórach, a late-twelfth- or earlythirteenth-century ${ }^{7}$ reworking of a number of earlier Fenian narratives into a complex whole, proffers the hope of Christian salvation for the pagan warriors who had been followers of Finn - as shall be seen, the author of Reicne Fothaid Canainne was rather less optimistic about the prospect of Fenian salvation.

Given the importance of the Reicne for understanding the early development of the Fenian corpus, it is somewhat surprising that the text has only occasionally been the subject of criticism, the bulk of which has focused on historical and linguistic, rather than literary, concerns; only a few scholars have chosen to treat the text as a literary artefact, analysing its structure and thematic content, and much work remains to be done. ${ }^{8}$ It is a testament to the richness of the medieval Irish poetic corpus (and also to the paucity of scholars working in this area) that a poem as evocative, highly wrought, and richly woven with allusions as this has amassed so slender a body of scholarly criticism - had the Reicne been composed in Old English rather than Old Irish, even a cursory summary of the scholarship on the poem would run on for page after page. In the following essay, I closely examine the language and structure of the Old Irish prose text and the Reicne, making two interrelated arguments: (1) the texts invoke and rework themes associated with the 'sovereignty of Ireland' topos, particularly the role of the so-called 'woman of sovereignty' in the ascent and downfall of the ruler; and (2) the poem deploys rhetorical strategies aligning women, sexuality and death in opposition to the masculine, homosocial sphere of the fian, thereby drawing sharp, artificial divisions between Fothad and the female figures in the poem.

What follows is a literary study, but in developing my interpretation I have been influenced by anthropological and sociological approaches to death rituals and mourning cross-culturally; my title refers to an influential study on the intersection of death, pollution and gender in mortuary rites by the anthropologist Maurice Bloch. ${ }^{9}$ Here at the outset I will briefly outline a few of the theoretical positions that inform my reading of the Reicne and the associated prose narratives. In 1907 Robert Hertz published his seminal study of mortuary

${ }^{5}$ Proinsias Mac Cana describes Fothad Canainne as 'a figure still trailing behind him the remnants of a complex mythology', see Mac Cana, 'Fianaiegcht in the pre-Norman period', Béaloideas, 54-55 (1986-7), 7599: 78.

${ }^{6}$ On the church's attitude towards the fian in the early medieval period, see Richard Sharpe, 'HibernoLatin Laicus, Irish láech and the Devil's men', Ériu 30 (1979), 75-92, and Kim McCone, 'Werewolves, cyclopes, Díberga and Fíanna: juvenile delinquency in early Ireland', CMCS 12 (1986), 1-22.

${ }^{7}$ On the dating of the Acallam, see Ann Dooley, 'The date and purpose of Acallam na Senórach', Éigse 34 (2004), 97-126, and Anne Connon, 'The Roscommon locus of Acallam na Senórach', in Aidan Doyle and Kevin Murray (eds), In dialogue with the Agallamh: essays in honour of Seán Ó Coileáin (Dublin, 2014), 2159.

${ }^{8}$ Joseph Nagy, Conversing with angels and ancients: literary myths of medieval Ireland (Ithaca, 1997), 299-303; Jacqueline Borsje, 'The "terror of the night" and the Morrígain: shifting faces of the supernatural', in Mícheál Ó Flaithearta (ed), Proceedings of the seventh symposium of Societas Celtologica Nordica, Acta Universitatis Upsaliensis, Studia Celtica Upsaliensia 6 (Uppsala, 2007), 71-98; Murray, The early Finn Cycle, 152-9. There have been occasional attempts to demonstrate that Reicne Fothaid Canainne was a source for the conclusion of the Old Norse eddic poem Helgakviða Hundingsbana Qnnur; see Eleanor Hull, 'The Helgi Lay and Irish literature', in Roger Loomis (ed.), Medieval studies in memory of Gertrude Schoepperle Loomis (Paris, 1927), 265-75. Peter Dronke discusses Reicne Fothaid Canainne in the context of European texts, mostly ballads, in which the dead lover meets the living beloved; see Dronke, The medieval poet and his world (Rome, 1984), 167-207, especially at 182-4.

${ }^{9}$ Maurice Bloch, 'Death, women, and power', in Maurice Bloch and Jonathan Parry (eds), Death and the regeneration of life (Cambridge, 1982), 211-30. 
rites, 'Contribution à une étude sur la représentation collective de la mort'. ${ }^{10}$ In this work he considers the practice of secondary burial, and one focus of his discussion is the polluting, 'wet' stage of death, which must be completed before the dead individual is given a final funeral. During this period mourning is ongoing, while corpses decompose and the dead are believed to transition from being members of a living community to take their place in the afterlife; Hertz argues that it is during this period of transition, when the corpse is still at least partially enfleshed, that the dead are most likely to be perceived as dangerous to the living. ${ }^{11}$

Building on the work of Hertz and others, Bloch and Jonathan Parry have argued that rituals surrounding death and burial can function as an 'attempt to negate the unpredictability of death', and that 'the symbolic negation of the apparent arbitrariness of death is ... often accomplished by a rhetorical emphasis on what is being denied'. ${ }^{12}$ Furthermore, '(s)exuality, biological birth and death are made to represent an intrusion of the wild, the natural sphere of women. ${ }^{13}$ Speaking of the Bara culture of Madagascar, Bloch and Parry assert that

the symbolism of the mortuary rites ... identifies women with sexuality, and sexuality with death. Victory over death - its conversion into rebirth - is symbolically achieved by a victory over female sexuality and the world of women, who are made to bear the ultimate responsibility for the negative aspects of death. In line with this, the sexuality of women is often associated with the putrescence of the corpse. ${ }^{14}$

Bloch argues that cross-culturally it is primarily women "who are associated with the pollution of death. It is they who must wash the corpse and then wash themselves ... it is mainly they who ritually take on pollution by throwing themselves on the corpse'. ${ }^{15}$ As I shall argue, an association of women with the pollution of death is a prominent theme in the Reicne. Also of interest are Bloch's observations on the ways in which rites of passage can enact a symbolic and/or social exclusion of women:

(i)ndividual biological birth, like individual biological death, is elaborately represented as associated with women, only to be vanquished so that group unity is asserted by deme ${ }^{16}$ entry in the one case, and tomb entry in the other; ${ }^{17} . .$. the sociomoral birth, as opposed to the defiling biological birth, is thus equated in a number of ways to the social death, entry into the tomb. ${ }^{18}$

Bloch continues: 'the concept of birth and death are systematically collapsed in these rituals and made one by opposing them to an antithesis acted out by women, biological birth

${ }^{10}$ Robert Hertz, 'Contribution à une étude sur la représentation collective de la mort', Année sociologique 10 (1907), 48-137. All references to Hertz refer to the English translation: 'A contribution to the study of the collective representation of death', in Robert Hertz, Death and the right hand (Rodney and Claudia Needham (trans.); Glencoe, Illinois, 1960), 29-86.

${ }^{11}$ Hertz, 'Contribution to the study of the collective representation of death', 29-53. Hertz's theory has been applied by Nancy Mandeville Caciola to medieval European accounts of revenants; see Afterlives: the return of the dead in the Middle Ages (Ithaca, 2016), 224-31, 238-44, 351-2.

${ }^{12}$ Maurice Bloch and Jonathan Parry, 'Introduction: death and the regeneration of life', in Bloch and Parry (eds), Death and the regeneration of life, 1-44: 12.

${ }^{13}$ Bloch and Parry, 'Introduction', 20.

${ }^{14}$ Bloch and Parry, 'Introduction', 22.

${ }^{15}$ Bloch, 'Death, women and power', 215.

${ }^{16}$ Bloch refers here specifically to the Merina of Madagascar; 'demes' are 'localised kin-groups' in Merina culture. 'Death, women and power', 211.

${ }^{17}$ Bloch, 'Death, women and power', 219-20.

${ }^{18}$ Bloch, 'Death, women and power', 220. 
and biological death. ${ }^{19}$ Admittedly, the majority of the cultures whose mortuary rites are analysed by Bloch and Parry are quite far removed from early medieval Ireland, not only temporally and geographically, but also in their cultural practices and religious belief systems; the phenomena they describe, however, are representative of widespread ways of thinking about death, gender and sexuality, and may help to shed some light on the ideologies that underlie the depiction of death and pollution in the account of Fothad's demise. Finally, it must be emphasised that while the setting of the texts under consideration is several centuries before Christianity was adopted in Ireland, the texts themselves were produced long after the conversion of the Irish. The poet who composed the Reicne seems to have had a pronounced interest in, for want of a better term, 'mythological' figures and themes, but as with all medieval Irish authors, he was working within a thoroughly Christian milieu.

Before proceeding with my analysis, it will be helpful to summarise the texts under consideration. The Old Irish prose narrative is brief, and lays out the information that is essential to understanding the genesis of the poem. Fothad and his rival, Ailill mac Éogain, are introduced, and the text explains that Fothad's figure is superior to Ailill's, but that Ailill's wife is fairer than Fothad's. Fothad sends his follower Failbe Flann to woo Ailill's wife. She demands miach hoir 7 miech findruine 7 miech cre[d]umae ('a sack of gold, a sack of findruine and a sack of bronze') ${ }^{20}$ as her tindscra ('bride-price'). Fothad agrees to this condition, and she asks how it will be paid. It is explained that:

patar se semanta hi sleig cech fir to muintir Fothith .i. da sem óir 7 da sem arcit 7 da sem chreduma. Nogetaiss tri semanna ar cach sleig 7 fogebtais a tri fo gach ae 7 nolinfatis tri meich dibh .i. miach óir 7 miech arcit 7 miach creduma. ${ }^{21}$

there were six rivets on the spear of each man of Fothath's household, namely two rivets of gold and two rivets of silver and two rivets of bronze. Three rivets would be taken away to the detriment of each spear and three would (still) be found on each of them and three sacks would be filled with them, namely a sack of gold and a sack of silver and a sack of bronze. ${ }^{22}$

The price is agreed and the lovers set out to make their tryst. That same night, Ailill pursues the lovers, the two warbands meet, and Fothad is killed. His head sings the Reicne to his lover in the grave-mound.

The Middle Irish prose text is much longer than the earlier version, incorporating etymological and genealogical material to expand upon the bare outline offered in the earlier text. It begins with a lengthy account of Fothad's birth and parentage, explaining that Fothad is a triplet, and that his two brothers are also named Fothad. After expounding upon the meaning of the names of the brothers, the text introduces the rivalry between Fothad

\footnotetext{
${ }^{19}$ Bloch, 'Death, women and power', 220.

${ }^{20}$ Hull, 'Death of Fothath Cananne', 401, 403. I have silently normalised editorial length-macrons in older editions to Irish length marks.

${ }^{21}$ There may be an allusion to Ailill's wife's tindscra in Tochmarc Ferbe, when the richness of the equipment of the Connacht warriors accompanying Maine to his doomed wedding feast is described at length. It recounts that each man's spear had fifty rivets of gold and fifty rivets of findruine on it, and that if each man were required to pay a bushel of gold, a rivet taken from the spear of each would pay it; see Ernst Windisch (ed. and trans.), Tochmarc Ferbe, in Ernst Windisch and Whitley Stokes (eds), Irische Texte mit Wörterbuch, 3:2 (Leipzig, 1897), 445-556: 464.

${ }^{22}$ Hull, 'Death of Fothath Cananne', 401, 403.
} 
Canainne and the other fian chief, here named Ailill Flann Bec. ${ }^{23}$ Otherwise the events leading up to the death of Fothad follow the account in the Old Irish text.

Fothad opens the Reicne by forbidding his lover to speak, then laments his own death and those of his fellow warriors. He bequeaths his treasures, described at length, to his lover. He warns her that she is in danger on the battlefield and should flee, and charges her to remember the Reicne and to raise a tomb over his grave. Fothad describes the Morrígain, the Irish goddess associated with war and death, laughing as she washes the entrails of the dead, an early instance of the Washer at the Ford motif. ${ }^{24}$ In the penultimate verse, Fothad states that his soul is to be tortured by Donn (the 'Dark One' or 'Dusky One') and that serc bethu cé is miri, ingi adradh Righ nimhi ('save for the worship of Heaven's King, love of this world is folly'). ${ }^{25}$ Fothad hears a lon ('blackbird') laughing imc[ $\left.h\right]$ omarc cáich bes hires ('a greeting to all the faithful') in the final verse, and declares that his shape and speech are spectral. ${ }^{26}$ The poem closes with a dúnad, as Fothad repeats his opening command that his lover remain silent.

The two versions of the introduction to Reicne Fothaid Canainne are never united with the complete poem in a surviving manuscript; however, each introduction concludes by reproducing the beginning of the Reicne: the initial line is quoted in the Middle Irish prose text, and the first verse is reproduced in its entirety in the Old Irish prose narrative. The extent to which the surviving poem matches the versions to which the authors of the prose narratives had access cannot be known, but the information supplied in them does not contradict the poem, with one significant difference: both prose narratives describe the head of Fothad singing the poem to Ailill's wife, while in the poem Fothad refers, in the second verse, to his corpse and head lying on the battlefield, and, in the final verse, describes his speech and shape as siabra ('spectral').

For the purposes of the present argument I will focus on the Old Irish texts, bearing in mind the possibility that the prose text may never have been joined to the poem in its entirety in a single manuscript, and that the poem known to the author of the Old Irish prose narrative may have differed to some degree from the extant version. It is clear that the authors of the Old Irish prose text were familiar with the poem in some form, and intended the prose text to provide context for the Reicne, thus it makes sense to examine them together. At the conclusion of this study, I will also briefly consider the manner in which the Middle Irish prose text reworks and augments the themes of the Old Irish prose text (and the Reicne).

${ }^{23}$ It is not clear to me why the Middle Irish author uses a different name here to that found in the poem and the earlier version of the prose text. Fothad's enemy is named Ailill mac Éogain in the poem (v. 22), but there is no guarantee that the Middle Irish author had access to the version of the poem that is extant. It is possible that the reference to Fothad's father, Macnia, that is, Lugaid Mac Con, may have prompted the author of the Middle Irish prose text to think of the Munster king Ailill Flann Bec: Lugaid Mac Con was said to have met his death at the hand (well, the tooth) of Ailill Ólomm, Ailill Flann Bec's great-grandfather, and thus we would have an inter-generational rivalry; however, this is but one of the several possible genealogies for Fothad. Peter McQuillan summarises the conflicting genealogical material on Fothad Canainne in 'Finn, Fothad, and fian: some early associations', Proceedings of the Harvard Celtic Colloquium 8 (1988),1-10: 1-3. In v. 14 of the Reicne, Fothad states that Flann Bec has fallen in the battle. This must be one of the three Flanns who were followers of Fothad and to whom he refers in the previous verse, but it is possible that this line has been misunderstood by the author of the Middle Irish text.

${ }^{24}$ This motif is attested from the Old Irish period, and survives into modern folklore; see Patricia Lysaght, The Banshee: the Irish supernatural death-messenger (Dublin, 1986), 197-202; Gertrude Schoepperle, 'The Washer of the Ford', Journal of English and Germanic Philology 18 (1919), 60-66.

${ }^{25}$ Meyer, Reicne, v. 48.

${ }^{26}$ Meyer, Reicne, v. 49. 
The Reicne is composed in various forms of deibide, except for verses 21,31 and $39{ }^{27}$ The poem is called a reicne in the prose texts and in verse 46. As to what, precisely, a reicne is, no firm conclusion has been reached. In a 1943 article on the text, Vernam Hull observed that 'the precise meaning of reicne has not as yet been established' ${ }^{28}$ regrettably, this situation persists. The DIL offers the tentative definition '(a) kind of poetical composition of which there was more than one species; perh. orig. a rhapsody or extempore poem. ${ }^{29}$ The two laments that Deirdriu sings after Noísiu's death in Longes mac nUislenn are both referred to as reicne ${ }^{30}$ and the early fifteenth-century Lecan Glossary contains the entry Reigne $i$. marbnath ${ }^{31}$ ('reicne, i.e. elegy'). Reicne is sometimes used to refer to specific metres, ${ }^{32}$ and the term appears in the version of Verba Scáthaige found in Tochmarc Emire in Lebor na hUidre. Scáthach prophesies Cú Chulainn's future exploits. After she welcomes him, she declares: nibá fortacht can recni / nibá recni can decni ${ }^{33}$ ('there shall be no succour without reicne / there shall be no reicne without deicne' [my translation]). We are hindered in interpreting these lines because decni appears to be a hapax legomenon. ${ }^{34}$ 'There shall be no succour without lament' does make sense, though whether the fortacht refers to Scáthach's training of the young hero or to future assistance that he will receive from others is not made explicit, and if reicne does mean 'lament' in these lines, it is unclear who will be lamenting for whom.

Reicne also occurs in the Fer Diad episode in the Stowe version of Táin Bó Cúailnge, where it is said of the releasing of the gáe bulga, that uair ni tabhartha gan recne rabaid roimhi" ("it was not to be cast without a reicne of warning [or: "notice"?] before it'). If reicne means 'lament' here, the meaning would seem to be that the weapon is so deadly that a death was assured when it was employed in battle, thus necessitating a lament for the man against whom it was cast. On the other hand, if we take the reference to a recne rabaid in the Fer Diad episode and the recni in Verba Scáthaige to support the possibility that reicne had a premonitory connotation, this would also fit the context of the Reicne Fothad Canainne, given that Fothad does warn his lover to flee in order to avoid horrors on the battlefield. Considered as a whole, the evidence supports the argument that reicne often, though perhaps

${ }^{27}$ Meyer, Reicne, 3.

${ }^{28}$ Vernam Hull, 'Reicne Fothad Canainne', Modern Language Notes 58 (1943), 29-31, at 29, fn. 1. Hull mentions this lack of explanation by way of justifying his decision to leave reicne untranslated in the title of his article. Translations of the poem into English have avoided this difficulty by giving the poem titles that refer to the poem's content: the text is titled 'The dead lover' by David Greene and Frank O'Connor, and 'The tryst after death' in Meyer's translation. See David Greene and Frank O'Connor, A golden treasury of Irish poetry, A.D. 600 to 1200 (London, 1967), 86-92, and Kuno Meyer, Selections from ancient Irish poetry (London, 1911), 9-14.

${ }^{29}$ DIL, s.v. reicne.

${ }^{30}$ Vernam Hull (ed. and trans.), Longes mac nUislenn: the exile of the sons of Uisliu (New York, 1949), 48, 50. For commentary on this passage, see Kate Louise Mathis, 'Mourning the maic Uislenn: blood, death, and grief in Longes mac n-Uislenn and "Oidheadh chloinne hUisneach"', SGS 29 (2013), 1-20, 1-3. I am indebted to Kate Mathis for sharing a copy of her article with me.

${ }^{31}$ Whitley Stokes, 'The Lecan glossary', Archiv für Celtische Lexikographie 1 (1900), 50-100: 56, entry 278 .

${ }^{32}$ Whitley Stokes, 'The Bodleian Amra Choluimb chille', RC 20 (1899), 31-55, 132-183, 248-289, 400-437: 147; Whitley Stokes and Ernst Windisch, Irische Text mit Übersetzungen und Wörterbuch, 3.1 (Leipzig, 1891), 49.

${ }_{33}^{3}$ P.L. Henry, 'Verba Scáthaige', Celtica 21 (1990), 191-207, 11 5-6.

${ }^{34}$ DIL, s.v. decni.

${ }^{35}$ TBC St, 11 3252-53. O'Rahilly observes that the Stowe version of the text is 'based firmly on $l$, the archetype of the LL-[Book of Leinster] version' (viii); assessing the relationship among the versions of the Fer Diad episode found in various recensions of the Táin is, however, a complex task. O'Rahilly discusses the Fer Diad episode at length in her introduction, at xxiv-xxix. 
not always, meant 'lament.' The Reicne does share many elements with the genre of lament as found in medieval Ireland and elsewhere, in that it commemorates the dead whilst expressing the speaker's own grief, although Fothad's status as both the speaker and one of the fallen is certainly unusual.

\section{FOTHAD’S FALL}

The theme of a relationship between a female figure personifying sovereignty and a ruler is widespread in medieval Irish literature. ${ }^{36}$ Earlier examinations of the sovereignty theme preferred to categorise some figures as 'sovereignty goddesses', but more recent scholarship has tended to take the view that a woman may assume the role of 'sovereignty' in a given text, without being confined to or reduced to it. Whatever its putative mythological origins, the theme of the female figure who represents rule over a territory and is symbolically married to the rightful ruler retained rhetorical capital long after the conversion of Ireland rendered belief in territorial goddesses untenable from a theological point of view. Rather than a static representation of a moribund mythological motif, the function of the woman of sovereignty shifts according to the needs of the individual text. In an important study of the sovereignty-goddess theme, Máire West argues that the sovereignty goddess who establishes the king's rule at the beginning of his reign also has a hand in ending it when the king ceases to be a viable ruler. ${ }^{37}$ West observes that a 'mysterious woman' appears in some of the deathtales of Irish kings:

(s)he may be compared, if not identified, with the Sovereignty Goddess in accession tales ... her role here seems to be that of a death goddess, in that she provokes the downfall and death of the unjust king when the union between him and his realm has been irreparably damaged by his actions. ${ }^{38}$

In Fothad's attempted usurpation of Ailill's wife, there are strong echoes of the topoi not only of the accession of a king to rulership, but also of the eventual failure of his kingship. Fothad's actions make it clear that he is no longer fit to rule his fian. In making this argument I expand the theoretical model of the downfall of a king in medieval Irish texts to include Fothad; while Fothad does not rule over a physical kingdom per se, he is a rígféinnid, commanding a powerful warband, and son and brother to kings. ${ }^{39}$ It has also been proposed

${ }^{36}$ Pronsias Mac Cana, among others, has argued for this theme's circulation broadly within Celtic, especially medieval Irish, culture; for the seminal study on the topic see his series of articles: 'Aspects of the theme of king and goddess in Old Irish literature', EC 7 (1955-6), 76-114, 356-413; EC 8 (1958-9), 59-65. See also Máire Herbert, 'Goddess and king: the sacred marriage in early Ireland', Cosmos 7 (1992), 264-75.

${ }^{37}$ Máire West (as Máire Bhreathnach), 'The sovereignty goddess as goddess of death?' ZCP 39 (1982), 243-260, passim.

${ }^{38}$ West, 'Sovereignty goddess', 244-5.

${ }^{39}$ The applicability of this model to the leader of a warband is muddied by the absence of a clear understanding of what precisely the title rigféinnid means. For the first element of the compound, the DIL offers ' $r$ ' $g$-stem of ríking, used to form compds. (a) royal, pertaining to a king or chief, (b) pre-eminent of its kind; great, immense'. The DIL defines rigféinnid as 'a leader of a fian'. Does the rig-element indicate that the rigféinnid is of royal blood, or might it refer to the aristocratic origins of the youths who are members of the fian? Such questions are important, but beyond the scope of the present study. The Middle Irish prose text of Reicne Fothaid Canainne names Lugaid mac Con, legendary high-king of Ireland, as Fothad's father, and according to Do flaithiusaib hÉrend, Fothad's two brothers jointly held the kingship for a year until Fothad Cairptech was slain by Fothad Airgthech; see R.A. Stewart Macalister (ed. and trans.), Lebor gabála Érenn: the book of the taking of Ireland (5 vols), vol. 5, ITS 44 (Dublin, 1942), 341-2. There is textual evidence indicating that in the period in which the fian was still an active institution, kings would sometimes have been members of a fían prior to becoming rulers; see McCone, 'Werewolves, cyclopes, Díberga and Fíanna', 9-10. 
that Fothad was originally an 'ancestor deity' of the Uaithni. ${ }^{40}$ His downfall, narrated in both of the prose texts and alluded to in the Reicne, transpires swiftly, when he attempts to obtain for himself the wife of his rival Ailill. Joseph Nagy reads Fothad's wooing of Ailill's wife as part of a broader tendency to 'seek persons or objects that will represent him authoritatively, signs that he can manipulate and call his own. ${ }^{41}$ I am in complete agreement with Nagy's assessment, and I would like to draw attention to the manner in which Fothad's motivation is worded in the text: Pa hamru delp Fothith handas delp n-Oilella acht pa hamru ben n-Olella 7 ba haldiu indas pen Fothith ('Fothath's figure was more wonderful than Oilill's, but Oilill's wife was more wonderful and she was more beautiful than the wife of Fothath.' ${ }^{42}$ This may be compared with the Irish topos of the ben/fer a dingbálae 'his/her matching partner', ${ }^{43}$ in which it is imperative that both partners be of equal physical perfection. I will return to this point later.

The text does not explain how Ailill's wife first came to Fothad's attention, nor whether her interest was already established before he sent his emissary to woo her, but she is clearly receptive to his advances, immediately naming her price for abandoning Ailill in favour of Fothad. Compare this to Étaín's first meeting with Eochaid Feidlech in Togail Bruidne Da Derga. Étaín is spied bathing at a well by Eochaid. The text describes Étaín's appearance in great detail and at considerable length - Ralph O'Connor wryly observes that the narrator is 'nowhere more male than here ${ }^{44}$ _ and it is said that no other woman's beauty can match hers. Eochaid sends a follower to greet her, and the king gets to the point straightaway, asking if Étaín will consent to sleep with him. He is pleased to learn that doing so was her motivation for leaving the sid, and promptly agrees to give her an appropriate tindscra. An inversion of the positive deployment of the woman of sovereignty topos is found in the death-tale of Muirchertach Mac Erca, who likewise meets a mysterious woman calling herself by the name Sín (among others). He immediately thinks that he would give all of Ireland to spend a single night in her bed. She claims to have come to him out of love for him, and requires a coma ('gift') from him. He offers her wealth and the pleasures of royal life, but she refuses these, demanding instead that he never speak her name, that his wife never be permitted near her, and that his clerics be turned out of the household. ${ }^{45}$ Medieval Irish literati were conversant with, and also willing to subvert, these tropes: for example, when Fráech tries to negotiate Findabair's tindscra with her father, Ailill—a course that Fráech embarks upon only after failing to persuade her to run off with him-he scoffs at Ailill's demand, declaring that he would not pay such an extravagant tindscra even for Medb herself; ${ }^{46}$ surely this is the author winking at the audience about Medb's sovereignty associations.

Several features are shared among these three texts: the woman's superior beauty (in some cases matching the man's); her request for her tindscra; the ruler's willingness to make extravagant, perhaps even foolish, sacrifices to obtain her. I do not mean to suggest that men going to great lengths in pursuit of beautiful women is in any way unusual in medieval Irish

\footnotetext{
${ }^{40}$ Thomas F. O’Rahilly, Early Irish history and mythology (Dublin, 1946), 10.

${ }^{41}$ Nagy, Conversing with angels and ancients, 299-300.

${ }^{42}$ Hull, 'Death of Fothath', 401-2.

${ }^{43}$ Damian McManus, 'Good-looking and irresistible: the hero from early Irish saga to classical poetry', Ériu 59 (2009), 57-109: 64.

${ }^{44}$ Ralph O'Connor, The destruction of Da Derga's hostel: kingship and narrative artistry in a mediaeval Irish saga (Oxford, 2013), 58.

${ }^{45}$ Lil Nic Dhonnchadha (ed. and trans.), Aided Muirchertaig Meic Erca (Dublin, 1964), 1-2.

${ }^{46}$ Wolfgang Meid (ed. and trans.), The romance of Froech and Findabair or The driving of Froech's cattle: Táin Bó Froích, Innsbrucker Beiträge zur Kulturwissenschaft, Neue Folge 10 (Innsbruck, 2015), 44, 11 $150-1$.
} 
literature (or in any other literature with which I am acquainted), but the particular circumstances in which Fothad meets his death share striking similarities with the other tales, albeit in a stripped-down, simplified fashion. Of course, Ailill's wife is not the only great beauty in the passage, for Fothad himself is declared to be fairer in form than his rival. This detail is significant not only because it sets up the initial dilemma that the most beautiful man does not have a matching beauty as his wife, but because male beauty was also subject to considerable scrutiny in medieval Irish literature: it was essential that a ruler not only be wise and skilled in battle, he must also be perfect and without blemish in his delb 'form. ${ }^{47}$ Furthermore, that the woman pursued by Fothad is the wife of a rival fits well within the medieval Irish discourse on male desirability, in which ' $(\mathrm{t})$ he irresistibility of the hero touches not only the young, unattached girls but also mature, married womenfolk, and the greatest kudos of all, perhaps, lies in seducing the wives of mortal enemies. ${ }^{48}$

Fothad's decision to pay Ailill's wife's price with the rivets from his men's weapons implies an exchange of like for like: Ailill's beautiful wife, like the splendid gold-adorned weapons carried by Fothad's retinue, is an ornament demonstrating the superiority of the man with whom she has aligned herself. The removal of the rivets is also indicative of a failure in leadership: by removing the rivets from his warriors' spears, he impairs their ability to fight. Seim ('rivet') appears to have acquired a secondary meaning 'a supporter, follower', 49 underscoring the gravity of Fothad's error: his willingness to part with half of the rivets means that he will lose them all, on both the literal and metaphorical level. The nexus between weapons, status and masculinity in medieval Ireland needs little elaboration; by way of example, consider the theft of Fergus mac Róich's sword while he trysts with Medb in Táin Bó Cúailnge ${ }^{50}$ Furthermore, there appears to have been a particular association between spears and the warriors of a fian. ${ }^{51}$ By undercutting their ability to fight, Fothad betrays his men. He is the only person who stands to benefit directly from the seduction of Ailill's wife, though perhaps the prospect of humiliation heaped upon the rival war-leader may have appealed to the warriors of the Connacht fian. Fothad is acting in his own self-interest, in a manner that directly contravenes his obligation to his warriors. The dismantling of the men's weapons underlines the destabilisation that Fothad wreaks upon the social world of his fian. His decision to pay the tindscra in rivets from the weapons has the ominous air of the violation of a geis. ${ }^{52}$ Fothad's giving of the rivets is undertaken with a shocking casualness: depleting the strength of your warriors at the precise moment when you abscond with another powerful warleader's wife verges on the suicidal. The payment of the tindscra foreshadows the disastrous outcome of Fothad's pursuit of Ailill's wife.

In this interpretation, Ailill's wife initially plays a part similar to that of Sín in Aided Muirchertaigh Meic Erca: like Sín, she possesses an unsurpassed beauty that prompts Fothad to set aside his own wife in order to bring her to his bed, and also causes him to abandon his responsibilities to his dependants, decisions that lead directly to his death. As is the case with many of the female sovereignty figures discussed by West, Ailill's wife is never referred to

\footnotetext{
${ }^{47}$ See McManus, 'Good-looking and irresistible', 58-74, for an excellent discussion and survey of descriptions of male beauty in early Irish texts. See also the discussion in Kim McCone, Pagan past and Christian present in early Irish literature (Maynooth, 1990), 121-23.

${ }^{48}$ McManus, 'Good-looking and irresistible', 70.

${ }^{49}$ DIL, s.v. seim.

${ }^{50} T B C 1,33$.

${ }^{51}$ McCone, 'Celtic and Indo-European origins of the Fían', 16, 18-20, 27, 29.

${ }^{52}$ Given his beheading, it is somewhat ironic that in the text Bruiden Atha Fothad is said to be under a geis not to drink ale unless in the presence of severed heads; see Kuno Meyer (ed. and trans.), 'Two tales about Finn', $R C 14$ (1893), 241-8: 242.
} 
by name, ${ }^{53}$ an ambiguity that permits the nameless mortal woman, whose only features in the text are her beauty and her willingness to betray Ailill, to assume an abstract, if not mythological, mantle: her request for her tindscra gives Fothad the chance to choose wisely, thus demonstrating his continued fitness to rule, or foolishly; fittingly, his poor choice is instrumental in his death.

It has been observed that liquids often play a significant role in the king's or hero's demise $;{ }^{54}$ it may then be significant that Fothad and his men die at Féic, which, according to Meyer, is the same place as Linn Féic, a pool on the River Boyne. In the dindshenchas poem Brug na Bóinde I, the poet declares Atchíu lind find Féic na Fían/ frit aniar ('I see the clear pool of Fiacc of the warriors / west of thee') ${ }^{55}$ - might this be a reference to Fothad's fian? Linn Féic is so named because Conchobor's grandson Fíac(c) drowns there when he leaps into a deceptively shallow part of the Boyne co ro-thib tond tairis " ('so that a wave broke over him') in Cath Ruis na Ríg. Linn Féic is also one of the locations where Finn was said to have consumed the salmon of knowledge, ${ }^{57}$ a point to which I will return. A tenth-century poem states that Fráech was killed by Cú Chulainn at Linn finn Féic ('bright Linn Féic'), and that afterwards his mother, Bé Finn, wept over the branch with which Cú Chulainn had struck the mortal blow. ${ }^{58}$ Nearby is Cleitech, the sid of Elcmar after he loses Bruig na Bóinne to Óengus in Tochmarc Étaine. ${ }^{59}$ Cleitech is where Muirchertach Mac Erca dies, pierced by a spear, burned from the neck down, and drowned in a vat of the wine that the enchantress Sín had created from water drawn from the Boyne, with which she had been poisoning the king for some time. ${ }^{60}$ Another king, Cormac mac Airt, dies at Cleitech after he has been exiled from the kingship in Tara; ${ }^{61}$ in some accounts of his death he chokes to death on the bone of a salmon caught in the Boyne. ${ }^{62}$ The great number of tales set in or near the Boyne Valley ensures that Fothad meets his end in a landscape richly layered with narratives that are concerned with the themes wisdom (or its absence), sovereignty, and death.

Several texts link Fothad with the enigmatic Caillech Bérri. A no longer extant tale, 'The love of Caillech Bérri for Fothad Canainne', is included in the two major medieval Irish tale lists, ${ }^{63}$ and Caillech Bérri is described in the Banshenchas as Callech Bérri búan bind

\footnotetext{
${ }^{53}$ West, 'Sovereignty goddess', 253.

${ }^{54}$ West, 'Sovereignty goddess', 256-9.

${ }^{55} M D$ vol. 2, 10-17: 10-11.

${ }^{56}$ Edmund Hogan (ed. and trans.), Cath Ruis na Ríg for Bóinn Todd Lecture Series 4 (Dublin, 1892).

${ }^{57}$ Kuno Meyer (ed.), 'Macgnimartha Find', RC 5 (1881-83), 195-204: 201-02.

${ }^{58}$ Irard mac Coisse, Apair damsa re Der Fáil (Máirín Ní Dhonnchadha (ed.) and Moya Cannon
} (trans.)), in Angela Bourke, et al. (eds), The Field Day anthology of Irish writing, vol. 4, Irish women's writing and traditions (New York, 2002), 306, v. 6. For discussion of the relationship between the Táin's account of Fráech's death and his near-death in Táin Bó Fraích, see: Donald E. Meek, "Táin Bó Fraích and other "Fráech" texts: a study in thematic relationships, part I', CMCS 7(1984), 1-37, and 'Táin Bó Fraích and other "Fráech" texts: a study in thematic relationships, part II', CMCS 8 (1984), 65-85; James Carney, 'Táin Bó Fraích and Táin Bó Cuailnge', in Studies in Irish literature and history (Dublin, 1955), 66-76, especially 75-6.

${ }^{59}$ Osborn Bergin and R.I. Best (eds and trans), 'Tochmarc Étaine', Ériu 12 (1938), 137-96: 146. While their exact location is difficult to pinpoint, Linn Féic and Cleitech appear to have been in close proximity to Rosnaree on the Boyne; see Geraldine Stout, Newgrange and the bend of the Boyne (Cork, 2002), 65, 68.

${ }^{60}$ Nic Dhonnchadha (ed.), Aided Muirchertaig Meic Erca, 27.

${ }^{61}$ Tucait innarba na nDessi i mMumain inso 7 aided Chormaic, in Lebor na hUidre, 1. 4379.

${ }^{62}$ Vernam Hull, 'Geneamuin Chormaic', Ériu 16 (1952), 79-85: 85; Maura Power, 'Cnucha cnoc os cionn Life', ZCP 11 (1917), 39-55: 43.

${ }^{63}$ Serc Caillige Berre do fothud Chanand and Searc Caille Berra do Fothad Canand are the forms of the name in the A list of tales. In the B list, the title is given as Searc Cailligi Berre de Focha Canainde, Serc Chaillighi Bérre do Fothad Canainne, and Serc Caillige Berrae do Fothad Canoinne in the various manuscripts; see Proinsias Mac Cana, The learned tales of medieval Ireland (Dublin, 1980), 48, 58. 
bunaid, ben Fhathaid Chanand ${ }^{64}$ ('Enduring Caillech Bérri of pleasing descent, wife of Fothad Canand'). She is best-known as the speaker of 'The lament of the old woman of Beare', in which she contrasts her many dalliances with princes during her seven periods of youth with her life as an aged nun. ${ }^{65}$ Seán Ó Coileáin has argued that her relationship to Fothad, who appears in the Corco Loígde genealogies, is one of several connections that she has with the Corco Loígde, and that 'in one of her manifestations she was probably regarded as the personification of the Corco Loígde kingship of Osraige'; ${ }^{66}$ it has also been proposed that as Buí, one of her names, the Caillech is the personified kingship of Tara ${ }^{67}$ In his discussion of the relationship between Fothad and the Caillech, Nagy suggests that she may be the wife of Ailill with whom he elopes in Reicne Fothaid Canainne ${ }^{68}$ but it is not impossible that the wife whom Fothad forsakes might, in some versions of the text, have been the Caillech; the nature of the extant material does not permit a firm identification in either direction.

One other text may be significant here. The prose and metrical dindshenchas on Carraic Lethderg describe Fothad's abduction of a woman named Lethderg, daughter of Conchobor mac Nessa. ${ }^{69}$ She grants her love to Fothad $i$-aislingeo ${ }^{70}$ ('in a dream'), and Fothad, accompanied by several companions, abducts her from her husband, Tromda mac Calatruim, whom he kills. The poem does not relate how Fothad's tryst with Lethderg ends. The woman's name is intriguing: she shares a byname with Medb Lethderg, who is described as having taken successive kings of Tara as her husbands; it was said that isi na leigedh ri a Temair gan a beth fein aigi na mnái ('she it was who would not allow a king in Tara without his having herself as a wife'), ${ }^{71}$ and she marries five generations of kings of Tara. ${ }^{72}$ Scholars have often assumed that the Lethderg of this dindshenchas is Medb Lethderg, prompting Peter McQuillan to ask:

Are we therefore to take it that there was a genuine tradition to the effect that Fothad Canainne had some claim to the high-kingship of Leinster and also of Tara? Or simply the outsider asserting his right to some share in the sovereignty? Or the féinnid as woman-stealer? ${ }^{73}$

The Lethderg of this text does not, however, have the same parentage as the better-known Medb Lethderg, and we should be cautious in assuming that the Lethderg whom Fothad

${ }^{64}$ Margaret Dobbs (ed. and trans.), 'Ban-shenchus [part 1]', RC 47 (1930), 283-339, at 302.

${ }^{65}$ The most recent edition of this poem is Donncha Ó hAodha, 'The lament of the old woman of Beare', in Liam Breatnach, Kim McCone and Donnchadh Ó Corráin (eds), Sages, saints, and storytellers (Maynooth, 1989), 308-31.

${ }^{66}$ Sean Ó Coileáin, 'The structure of a literary cycle', Ériu 25 (1974), 88-125: 109-11.

${ }^{67}$ Tomás Ó Cathasaigh, 'The eponym of Cnogba', Éigse 23 (1989), 27-38.

${ }^{68}$ Nagy, Conversing with angels and ancients, 303.

69 'Carraic Lethderg', $M D$ vol. 4, 120-3: 120. Whitley Stokes (ed. and trans.), 'The prose tales in the Rennes dindshenchas', RC 16 (1895), 31-83, 135-67, 269-312, 468, at 43-4.

70 'Carraic Lethderg', $M D, 120$.

${ }^{71}$ Tomás Ó Máille, 'Medb Chruachna', ZCP 17 (1928), 129-46: 137-8. Matthias Egeler points out that this quote is taken from a fifteenth or sixteenth century section of $L L$; whether this tradition was current when Reicne Fothaid Canainne was composed is uncertain; seeMatthias Egeler, "Some thoughts on "goddess Medb" and her typological context', ZCP 59 (2012), 67-96: 75, fn. 46.

${ }_{72}$ Egeler evaluates Medb Lethderg's relationship to Medb of Connacht, who is also a figure associated with sovereignty; see Egeler, 'Medb', 75-6. Anne Connon provides a useful overview of Medb Lethderg in the textual record: 'Prosopography II: A prosopography of the early queens of Tara', in Edel Bhreathnach (ed), The kingship and landscape of Tara (Dublin, 2005), 225-327, 338-57, at 234-7.

${ }^{73}$ McQuillan, 'Finn, Fothad, and fían', 3. 
courts and the Medb Lethderg who espouses the kings of Tara are one and the same. ${ }^{74}$ Nonetheless, several details in the dindshenchas on Carraic Lethderg do align with the cluster of motifs occurring in narratives about sovereignty: Lethderg has dreamed of Fothad and fallen in love with him from afar; she is the daughter of a king; Fothad abducts her, killing her husband in the process. Even if this Lethderg is not the Medb Lethderg of Tara fame, that does not necessarily strip her of the resonances that her name may have borne. There is one intriguing discrepancy between the Carraic Lethderg texts and the Reicne: the prose dindshenchas state that Fothad's abduction of Lethderg occurred after the death of Ailill mac Éogain. ${ }^{75}$ Is this an error, or were there variant traditions in which Fothad survived his battle with Ailill?

Some of the parallels introduced above postdate the composition of the Reicne and the Old Irish prose text, but if the woman of sovereignty topos is a survival of genuine preChristian belief, then it would have been available in the period in which the Old Irish texts were composed. The early Irish church engaged in a lengthy process of integrating 'native' ideologies of rulership within a Christian framework. Kim McCone has discussed a number of texts that are from the Old Irish period that Christianise the concept of sovereignty. ${ }^{76}$ Pointing out numerous Biblical parallels for the personification of a city or territory as a woman, McCone states that

pre-Christian Irish kingship would constitute a typological anticipation of its Christian counterpart, and the woman of sovereignty, instead of being an antiquarian pagan anomaly, would have acquired a narrative role in keeping with contemporaneous Christian notions of a kingship Dei gratia, in which the benefits of the ruler's truth flowed ultimately from God.

In the period in which the Old Irish texts were composed, however, the fian had not yet been fully demoted from dangerous reality to pleasing literary convention, and was still anathema to the clerical literati; no doubt the church would have found the prospect of two fiana destroying one another over a woman to be a fitting — even desirable — end.

\section{THE SPOILS OF WAR}

The Reicne proper begins with Fothad poised at the border between life and death, suspended between two states. He orders his lover to be silent in the initial lines:

\section{A ben, náchamaicille! ni friot atá mo menmo: \\ atá mo menma colléic \\ isind imairiuc oc Féic.}

'Hush, woman, do not speak to me! My thoughts are not with thee. My thoughts are still in the encounter at Féic. ${ }^{, 78}$

\footnotetext{
${ }^{74}$ Murray, The early Finn Cycle, 156, fn. 30.

${ }^{75}$ Whitley Stokes, 'Prose tales in the Rennes dindshenchas', 43.

${ }^{76}$ McCone, Pagan past and Christian present, 138-60.

${ }^{77} \mathrm{McC}$ Cone, Pagan past and Christian present, 155.

${ }^{78}$ Meyer, Reicne, v. 1.
} 
By commanding her silence, Fothad assumes control of the Reicne; the bereaved widow, whom we would expect to perform the laments for both Fothad and Ailill, is pressed into the role of a mute observer. In the third verse, Fothad proclaims that:

Dochta do neoc $[h]$ dáles dáil

fácbas dáil n-éco fri láimh;

in dál dálto co Clárach

tuärnect im robánadh'

'It is blindness for anyone making a tryst to set aside the tryst with death: the tryst that was made at Clárach has been kept by me in pale death. ${ }^{79}$

Verses five and six continue in this vein:

Ní mé m'aonor im-múr thol docóid fordal i ndá[i]l ban, ní ar ait $[h]$ biur cid ditt ágh, is duäigh ar ndedhendál.

Do céin doroächt do dáil, bai gráin for mo choicne má[i]r, ma dofesmais bid amne,

bá assa ní tairistoe.

'Tis not I alone who in the fulness of desires have gone astray to meet a woman-no reproach to thee, though it was for thy sake-wretched is our last meeting!

I have come from afar to the tryst with thee; there was horror upon my noble companion. If we had known it would be thus, it had been easy not to persist. ${ }^{80}$

The insistent pairing of Fothad's two 'trysts' - the one with Ailill's wife and the one with death - in the initial verses of the poem directly links succumbing to the woman's allure to death in battle. ${ }^{81}$ This repetition suggests that on some level, the poet equates the two: Ailill's wife is death. Fothad refers to his dédendál ('last meeting', from déiden- 'last' + dál 'a meeting, a hostile meeting, an encounter'), ${ }^{82}$ with Ailill's wife in verse 5 . This term can also mean 'death', as it does in Saltair na Rann, in the couplet Ri rosáer Ezechiam slan / ciarb'focus adédendal ${ }^{83}$ ('The King delivered Ezechias safely, although his last encounter was near'). This potential double meaning further emphasises the structural relationship between Ailill's wife and Fothad's death.

Nagy observes that Fothad's 'final thoughts centred on the contrast between an active, heroic past informed by life among fellow fénnidi and a present shaped ... by a conflict over

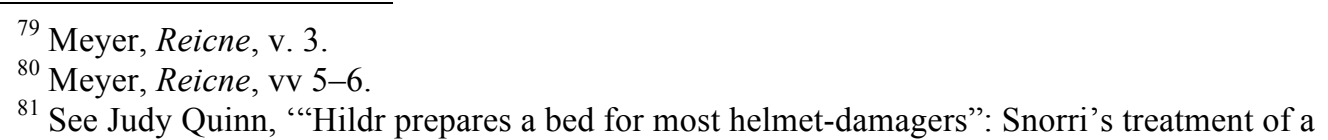
traditional poetic motif in his Edda', in Pernille Hermann, Jens Peter Schjødt and Rasmus Tranum Kristensen (eds), Reflections on Old Norse myths (Turnhout, 2007), 95-118, for a discussion of similar ideas in Old Norse texts.

${ }^{82}$ DIL, s.v. déiden-, dál.

${ }^{83}$ Whitley Stokes (ed. and trans.), Saltair na Rann: a collection of Early Middle Irish poems, Anecdota Oxoniensia, Mediaeval and Modern Series 1.3 (Oxford, 1883), 108, at 1. 7373-4. 
a woman and marked by a living death. ${ }^{, 84}$ The poet establishes a distinct contrast between the masculine and feminine spheres, with the living world of men juxtaposed with that of women and of death. All of his and Ailill's men are dead: Fothad's rash actions have destroyed the very system within which and by which his identity was constructed. Fothad's next rhetorical move is to resurrect verbally the materiality of the world he destroyed, in a turn that both memorialises the wealth of his fian and bequeaths both the objects and the memories to the living woman. The Reicne is Fothad's means of rebuilding that lost system through a cascade of names, heroic exploits, and rich gifts. He strives to recreate the world of the fian within structure the poem. Verses 7 through 22 detail the names and deeds of his dead warriors. Verses 24 to 40 contain elaborate descriptions of the fodb 'spoils' that Ailill's wife will inherit from Fothad. He gifts his erstwhile rival's wife with the treasures of the fian, recalling the sacks of gold, silver and white bronze that she demanded from him. Her tindscra becomes the inheritance of widowhood. Verse 40 specifies that these riches will provide wealth for her descendants in perpetuity. What descendants are these? Did she and Fothad consummate their tryst before Ailill's men ambushed them? Does she have children from her marriage to Ailill? Does Fothad anticipate her remarriage?

Fothad commands her to depart the battlefield, taking his spoils with her (v. 23): she is to claim his own crimson cloak and white tunic (v. 24), his spear and shield (v. 25), his white cup, golden rings and bracelets (v. 26), and gold and silver brooch that had once belonged to the hero Caílte (v. 27). He instructs her to unclasp the bronze torc from his neck (v. 28), a move that calls to mind his beheading. Twelve verses (vv 29-40), nearly a quarter of the poem, are lavished on Fothad's fidchell-set, and the poet's artistry is on full display in these lines. It verges on banality to observe that games often perform symbolic or metaphorical work in literary texts, but the number of verses dedicated to the fidchell-set indicates that we should attend carefully to what the poet is doing in this section. The precise rules of fidchell are not known, but it appears to have been a 'battle game', played by two players who each commanded half of the game pieces, with each player attempting to capture or kill the other's 'men'. ${ }^{85}$ That the game pieces are divided into two sides of equal number recalls the physical battle between Fothad and Ailill's fiana.

The fidchell board lies $i$ taob inn firt ('by the side of the grave', v. 30). Is this Fothad's own grave? Or another grave located in the landscape? Fert can refer to a tumulus or passage grave, and such graves were often reused over long periods of time; ${ }^{86}$ it seems likely that this is the kind of burial that the poet envisioned for Fothad. Fothad says of the fidchell board that 'noble blood drips upon its rim' (bruinnit ${ }^{87}$ fuil sóer for a bil, v. 29), and he describes the bodies of the 'spear-armed hosts' (cúan rinnech) lying 'here and there' (san $c[h] a n)^{88}$ around the board's red inlay (deircinnech, v. 30). In addition to 'host', cúan can also refer to a litter or pack of wolves or dogs, and the most basic meaning of the noun rind, from which the adjective rinnech derives, is 'point' or 'tip'; given the canine-associations that attend upon the fian in the literature, perhaps there is an intended double-meaning: 'speararmed hosts' as well as 'sharp-toothed (or "sharp-clawed"?) wolf pack'.

The description of the corpses of the dead warriors lying around the fidchell board beside the grave evokes the image of game-pieces left carelessly scattered after the players have finished their game. In contrast to the bloodied corpses strewn on the battlefield are the

\footnotetext{
${ }^{84}$ Nagy, Conversing with angels and ancients, 300.

${ }^{85}$ Eóin MacWhite, 'Early Irish board games', Éigse 5 (1945-47), 25-35: 31, 35.

${ }^{86}$ Elizabeth O'Brien and Edel Bhreathnach, 'Irish boundary ferta, their physical manifestation and
} historical context', in Fiona Edmonds and Paul Russell (eds), Tome: studies in medieval Celtic history and law in honour of Thomas Charles-Edwards (Woodbridge, 2011), 53-64.

${ }^{87}$ Meyer suggests reading bruinnit as bruinnid;see Reicne, 14, fn. 4.

${ }^{88}$ Meyer has sán $c[h] a ́ n$ in v. 30, but san $c[h]$ an in v. 41, where the short vowel is confirmed by rhyme. 
foirenn 'fidchell-men' of yellow gold and white bronze, which are carefully stored in a fourcornered ferbolc (literally a 'man-bag'). Foirenn in its broadest sense refers to 'an indefinite number of persons', but in its more restricted senses it can refer to a troop or company, or a set of figures used in playing board games, ${ }^{89}$ further underscoring the implicit comparison between the men and the game pieces. The image of spoils that are symbolically men will be inverted when the Morrígain arrives on the scene. Seven verses are devoted to the ferbolc itself. It is four-cornered and cunningly wrought, adorned with gold, red gold and white bronze (v. 35). Made by a master-smith, its lock can only be opened by a wise person, and a Roman emperor is said to have waged battle for its possession.

Fothad describes each clasp of the ferbolc as having a value equivalent to that of seven laichesa 'laywomen'- perhaps there is some irony in that the woman for whom such an extravagant payment of wealth (and lives) was paid would herself in turn receive a container whose clasps are valued at seven times her own worth, and that was sought by an emperor (vv. 36-38). The Reicne relates that the ferbolc was revealed to Finn after a wine banquet (v. 38). The image of grave-goods is evoked when Fothad claims that no king has ever been buried with such a treasure, and he urges the woman to take it and use it to provide for her children (vv 39-40). That this memorialising section of the poem concludes with an image of enclosure, of game pieces safely stored away, is surely intentional. Fothad will later enjoin his companion to remember the Reicne, with its account of his death and of the deeds of his fian; like the ferbolc containing the fidchell-men, she will carry Fothad's words away from the battlefield, kept safe in her memory.

The section describing the treasures is bracketed by references to fear and terror. In verse 23 Fothad warns his lover to flee aidc[h]e úath / i lleirc eter lectaibh cūan ('the terror of night on the battle-field among the resting places of the hosts'). ${ }^{90}$ After listing and describing the spoils that he is bequeathing to Ailill's widow, Fothad describes the Morrígain in verses 41 and 42:

\section{Atá[a]t immunn san c[h]an, mór fodb as a fordercc bol, dreman inathor dimar, nodusnigh an Mórríoghan. \\ Donárlaith do bil oigi, \\ Isí cotanasoíde, is mór do fodboibh nigius, dremhan an caisgen tibhes.}

'There are around us here and there many spoils whose luck is famous; horrible are the huge entrails which the Morrígan washes.

She has come to us from the edge of a pillar (?), 'tis she who has egged us on; many are the spoils she washes, horrible the hateful laugh she laughs. ${ }^{91}$

The abrupt shift from the spoils that the woman will receive to the spoils, that is, the entrails, in the possession of the Morrígain draws a clear parallel between Ailill's wife and the

\footnotetext{
${ }^{89}$ DIL, s.v. foirenn.

${ }^{90}$ Borsje discusses the term aidche úath at length, and argues that it may refer to a supernatural being; see Borsje, "'Terror of the night” and the Morrígain', 74-82.

${ }^{91}$ Meyer, Reicne, vv. 41-2.
} 
goddess, and also between the wealth stripped from the dead and the corpses of the slain men. Fothad's lover, like the Morrígain, is handling the physical remains of a dead warrior.

Fordercc ('famous') in verse 41 may be punning on forderg ('red on surface; very red [esp. of colour of blood]; common in fig. sense bloodstained, wounded; bloody, sanguinary'), ${ }^{92}$ reinforcing the correspondence between the treasures and the viscera. The Washer at the Ford is usually a premonition of imminent death, but it is not clear whether the premonition was thought to be a glimpse of the future 'reality' or was understood in purely symbolic termsthat is to say, was seeing the Washer at the Ford akin to someone seeing a funeral procession before the death had occurred, or was it more along the lines of a prophetic dream, the symbols of which must be interpreted? In contrast to other depictions of the Washer, the Morrígain's washing is post-mortem. This is among the earliest surviving examples of the motif, and it is difficult to determine whether the premonitory aspect of the Washer would have been well-known enough when the poem was composed for the Morrígain's appearance here to be understood as a subversion of the 'typical' deployment of the motif.

Fothad states that the Morrígain laughs and Rolá a moing dar a hais ('has flung her mane over her back'). ${ }^{93}$ He uses the term mong ('a head of hair, always of long and abundant, never close-cropped hair') for her hair, but this word may also be translated as 'mane', a meaning that emphasises the Morrígain's bestial associations. ${ }^{94}$ Her long, unconfined tresses are a trait that she shares with later manifestations of the Irish death-messenger. ${ }^{95}$ That Fothad speaks of having kept his tryst im robánadh ('in pale death') in the third verse is doubly significant; not only does he tarry with his living lover, but he is also now wellacquainted with the Morrígain. Her washing is a horrific parody of tonach, the ritualised washing of the dead in preparation for burial. Her pleasure is clearly at odds with what would normally be a solemn occasion. She revels in the pollution, absorbing it, permitting Fothad to distance himself from the horror that is his own dismembered body. As she laughs and tosses her hair amongst the wet and tattered corpses, her role as a goddess of death on the battlefield comes to the fore. Laughter is a multivalent gesture, and the Morrígain's laughter need not indicate that she is mirthful in any prosaic sense, but she does appear to display a high degree of enthusiasm for the task so gruesomely at hand. She is not handling the warriors' remains gingerly or with distaste. Just as Fothad symbolically destroyed the structural integrity of his fian by the removal of the rivets from their spears, the Morrígain literally deconstructs the bodies of the dead warriors. Unlike the scattered fidchell-men, safely tucked away in the womb-like ferbolc and entrusted to the care of Fothad's lover, the men of the fian are undone by the Morrígain: she uncoils their viscera, making what should be internal and contained visible and exposed, a chaotic inversion of the proper order.

As critics have often noted, the Morrígain has strong associations with sexuality, in addition to her connection to death in battle. Reconciling her warlike ferocity with her nurturing and sexual characteristics requires a rethinking of her function. Recently, critics have called for a reframing of the Morrígain, arguing that the duality of death and the erotic is deeply embedded in the figure. In the split nature of the Morrígain, Angelique Gulermovich Epstein sees a representation of the duality of war. ${ }^{96}$ Máire Herbert argues that 'whatever her

${ }^{92}$ DIL s.v. forderg.

${ }^{93}$ Meyer, Reicne, v. 43.

${ }^{94}$ DIL s.v. mong.

${ }^{95}$ Lysaght observes that the emphasis on this feature in folklore suggests that the death-messenger was envisioned as being bareheaded, which would connect her with older women whose hair would be loosened during keening and other mourning practices; see Banshee, 95-101, particularly at 97. She connects this feature to the Morrígain in the Reicne at 199.

${ }^{96}$ Angelique Gulermovich Epstein, War goddess: the Morrígan and her Germano-Celtic counterparts. Unpublished PhD thesis, UCLA (1998), 306. 
alter ego, the evidence so far indicates that war per se is not the sole aspect of the role of the goddess. She has significant associations with the earth and with the cattle-resources of a pastoral people. ${ }^{97}$ Like the 'woman of sovereignty', who appears both as a horrific hag and a beautiful woman, corresponding to the state of the land, the Morrígain shifts between beautiful and terrible aspects. This ambiguity is reflected in the various etymologies proposed for her name. The spellings Morrígain and Mórrígan are both represented in medieval texts, though the former occurs in earlier sources and is generally thought to be the original form of the name. Rigain, the second part of the name, is transparently the Old Irish word for 'queen', but the meaning of the first component is more obscure. If it is the adjective mór ('great'), then her name would mean 'Great Queen'. This is the etymology favoured by Herbert, ${ }^{98}$ but the lateness of 'Mórrígan' in the manuscript record suggests that this a more recent conceptualisation of the figure. If the first component is mor, it may reflect the same root as Old English meara, the 'mare' in nightmare, yielding the meaning 'Queen of phantoms' ${ }^{99}$ Alternatively, Kim McCone has proposd that the name may derive from *Moro-rignī, which would be understood as 'Queen of Death'. ${ }^{100}$

The parallels between the Morrígain and Ailill's wife may be pushed further. Ailill's wife is traversing a battle-field at night; according to the Middle Irish prose narrative she is carrying a severed, speaking head. The once masculine domain of the battlefield has now been occupied by women. The archetype of women searching among the slain on the battlefield for their men in order that they might be prepared for burial resonates here, as does the image found elsewhere in medieval literature of a loyal retainer conveying his lord's head to burial. ${ }^{101}$ While these are positive images that reinforce notions of order, in that it is proper to bury one's dead, the image of a woman carrying a talking head across a battlefield at night is surely horrific, and the dual implications of this image further destabilise the poem. Ailill's wife is the object of erotic desire in the text, but on the corpse-strewn battlefield she becomes an unsettlingly hybrid figure, embodying both the erotic and the macabre, in a manner comparable to the Morrígain. Ailill's wife and the Morrígain appear in the Reicne as twinned figures, a geminate representation of the duality of sovereignty. One is Fothad's (would-be) lover, mute at his command; the other, the ravenous goddess of battle, mocks him with laughter as she washes the entrails of the dead.

In other texts, a tryst with the Morrígain by the water is laden with erotic, albeit violent, promise. In Recension I of Táin Bó Cúailnge, Cú Chulainn's encounter with the Morrígain begins when she, disguised as the beautiful daughter of a king, propositions the young hero. When he refuses her, she threatens that she will impede his ability to fight at fords by taking the form of an eel that will trip him, a wolf that will drive herds of cattle into the water, and a heifer that will lead cattle to rush him. Here the sexual potential remains

\footnotetext{
${ }^{97}$ Máire Herbert, 'Transmutations of an Irish goddess', in Sandra Billington and Miranda Green (eds), The concept of the goddess (London, 1996), 141-51: 145.

${ }_{98}$ Máire Herbert, 'Transmutations', 142.

${ }^{99}$ For a useful summary of the various etymologies, see Matthias Egeler, Walküren, Bodbs, Sirenen. Gedanken zur religionsgeschichtlichen Anbindung Nordwesteuropas an den mediterranen Raum. Reallexikon der Germanischen Altertumskunde-Ergänzungsbände 71 (Berlin, 2011), 122-4. See also the discussion in Angelique Gulermovich Epstein, 'War goddess', 71-2.

${ }^{100}$ Kim McCone, 'Hund, Wolf, und Krieger bei den Indogermanen', in Wolfgang Meid (ed.), Studien zum indogermanischen Wortschatz. Innsbrucker Beiträge zur Sprachwissenschaft 52 (1987), 101-54: 141.

${ }^{101}$ For example, Brân's followers decapitate him at his request, convey his head to an otherworldly feast, and inter the head; see Derick S. Thomson (ed.), Branwen uerch Lyr (Dublin, 1961), 17. A similar situation may lie behind the enigmatic englynion describing a warrior carrying the head of Urien Rheged from a battlefield: Pen Urien, in Jenny Rowland (ed. and trans.), Early Welsh saga poetry: a study and edition of the englynion (Cambridge, 1990), 420-22 (text), 477-8 (translation), and 76-81 (commentary).
} 
unfulfilled, and her antagonism towards the hero dominates the interaction. ${ }^{102}$ In Cath Maige Tuired, the Dagda arranges a tryst with the Morrígain in Glen Edin near Samain, a notably liminal period. He goes to meet her:

Co n-acu an mnai a n-Unnes a Corand og nide, indarna cos di fri Allod Echae (.i. Echuinech) fri husci andes alole fri Loscondoib fri husce antúaith. Noi trillsi taitbechtai fora ciond. Agoillis an Dagdae hi 7 dogníad óentaich. Lige ina Lánomhnou a ainm an baile ó sin. Is hí an Morrígan an uhen-sin isberur sunn.

'He saw the woman at the Unshin in Corann, washing, with one of her feet at Allod Echae (that is, Aghanagh) south of the water and the other at Lisconny north of the water. There were nine loosened tresses on her head. The Dagda spoke with her, and they united. "The Bed of the Couple" was the name of that place from that time on. (The woman mentioned here is the Morrígan.), 103

The Dagda's tryst with the Morrígain is not devoted exclusively to pleasures of the flesh. After they copulate,

Itbert-si íarum frisin Dagdae deraghdis an Fomore a tír .i. a Maug (S)cé[t]ne, 7 ara garudh an Dagdae óes ndánu Érionn aro cend-si for Ádh Unsen; 7 noragad-si hi Scétne do admillid [ríg] na Fomore .i. Indech mac Déi Domnann a ainm, 7 dohérudhsi crú a cride 7 áirned a gailie úadh. Dobert-si didiu a dí bois den crú-sin deno slúagaib bátar ocon indnaidhe for Ádh Unsen. Bai 'Áth Admillte' iarum a ainm ónd admillid-sin an ríog.

'Then she told the Dagda that the Fomoire would land at Mag Céidne, and that he should summon the áes dána of Ireland to meet her at the Ford of the Unshin, and she would go into Scétne to destroy Indech mac Dé Domnann, the king of the Fomoire, and would take from him the blood of his heart and the kidneys of his valour. Later she gave two handfuls of that blood to the hosts that were waiting at the Ford of the Unshin. Its name became "The Ford of Destruction" because of that destruction of the king., 104

Gulermovich Epstein points out that what the Morrígain is washing when the Dagda observes her is not made explicit; earlier translators take it for granted that she is washing herself, but the text is not clear on this point. Gulermovich Epstein proposes that this passage

${ }^{102}$ TBC I, 57. Egeler argues that the Morrígain belongs to a class of female supernatural figures associated with death in battle, represented in Irish, Norse and Mediterranean cultures; he puts forward a compelling case for a relationship among the Irish Morrígain and Bodb, Norse Valkyries, and certain Greek and Roman figures. They often have avian associations and are highly sexualised, and are sometimes represented as devouring the dead or escorting them to the land of the dead. It is important to note that the entire constellation of characteristics is not present in each figure; for example, Egeler observes that 'the main differences between the Bodb and the Valkyries are that the Valkyries may not devour corpses, whereas the Bodb does not seem to be closely linked to the transition of the deceased to the realm of the dead'; see Matthias Egeler, 'Death, wings, and divine devouring: possible Mediterranean affinities of Irish battlefield demons and Norse valkyries', Studia Celtica Fennica 5 (2008), 3-24: 10-11; also Matthias Egeler, 'Textual perspectives on prehistoric contacts: some considerations on female death demons, heroic ideologies and the notion of elite travel in European prehistory', Journal of Indo-European Studies 37 (2009), 321-49.

${ }^{103}$ Elizabeth A. Gray (ed. and trans.), Cath Maige Tuired: the Second Battle of Mag Tuired, ITS 52 (Dublin, 1982), 44-5, §84.

${ }^{104}$ Gray, Cath Maige Tuired, 44-5, §85. 
might be read as another instance of the Morrígain as the Washer at the Ford, and connects the Morrígain's prophecy about the coming battle with other examples of the Washer foretelling the deaths of warriors. ${ }^{105}$ Elizabeth Gray makes a similar point, observing that though it is not explicitly stated that she is washing spoils, the Morrígain 'does display blood of the enemy king at the ford as a sign of his impending doom'. ${ }^{106}$ Gulermovich Epstein argues that in the Washer episode in Cath Maige Tuired the Morrígain 'function(s) as Sovereignty figure' and that she 'appears to be two things at once, the terrible Washer, foretelling destruction in battle, and a benign Washer, possibly symbolizing the union of the king and the land'. ${ }^{107}$ Given my reading of the Reicne as drawing deliberate parallels between Fothad's lover and the Morrígain, I tentatively propose that Fothad's encounter with the Morrígain at Linn Féic may have been intended as an allusion, inversion, or parody of the idea of the rightful king mating with the 'woman of sovereignty' at a ford.

\section{HATEFUl LAUGHTER}

The description of the Morrígain's laughter in verse 42, dremhan an caisgen tibhes ('horrible the hateful laugh she laughs'), has been compared to other incidents of laughing, ominous, supernatural women. ${ }^{108}$ Notably, the Reicne closes with another reference to laughter. In the final verse of the poem, Fothad tells his companion:

\section{Is é in lon teimhen tibius \\ imc $[h]$ omarc cáich bes hires, síabra mo c[h]obra, mo gné, a ben, náchamaicillé!}

'It is the dusky ousel that laughs a greeting to all the faithful: my speech, my shape are spectral- hush, woman, do not speak to me! ${ }^{109}$

The blackbird laughs (tibius), mirroring the Morrígain's laughter (tibhes, v. 42) earlier in the poem. These are the only two uses of the verb tibid in the poem, and the Morrígain's horrible laughter as she gloats over the slaughter is recalled by the lon's laughter. To what does Fothad refer when he speaks of the lon? The DIL has two headwords for lon: the first is defined as 'blackbird, (type of) ouzel'; the second occurs only in the phrases lon crais and lon int sáith, and may be the same word as lon $1 .{ }^{110}$ In the late eleventh- or twelfth-century Midle Irish tale Aislinge Meic Con Glinne, a king is afflicted with insatiable hunger by a lon crais ('lon of gluttony'). Meyer took this instance of lon to mean 'demon', translating the phrase as

${ }^{105}$ Gulermovich Epstein, 'War goddess', 175-6.

${ }^{106}$ Gray, Cath Maige Tuired, 97-8. Gulermovich Epstein argues that the Welsh marginalia in Peniarth 147 concerned with the placename Rhyd y Gyfartha ('The ford of the Barking') provides a parallel, combining the motif of the Washer at the Ford with a tryst; Gulermovich Epstein, 'War goddess', 175-6; text in Rachel Bromwich, Trioedd Ynys Prydein (3rd edn; Cardiff, 2006), 450. In that text, Urien of Rheged visits a ford that is known as a place where dogs go to bark. He finds a woman washing there, and has sex with her. She blesses him, and tells him she was fated to wash there until a Christian fathered a child on her. She reveals herself as the daughter of the king of Annwfn, the Welsh otherworld, and tells him to meet her at the ford in a year's time to claim their son. When the time comes, she gives him a son, Owain, and a daughter, Morfudd: see Bromwich, Trioedd, 195. Interestingly, this triad also mentions Nefyn, mother of Urien, Arawn and Lleu (or Urien and Efrddyl in a different version). Nefyn may be cognate with Irish Nemain. For Nemain's relationship to the Morrígain in Irish tradition, see Gulermovich Epstein, 'War goddess', 202-8.

${ }^{107}$ Gulermovich Epstein, 'War goddess', 178.

${ }^{108}$ Borsje, "“Terror of the night" and the Morrígain', 83, n. 38.

${ }^{109}$ Meyer, Reicne, v. 49.

${ }^{110}$ DIL, s.v. 1 lon, 2 lon. 
'demon of gluttony. ${ }^{111}$ The text does state that 'Sáttan' is the lon crais, ${ }^{112}$ so there is clearly a demonic element to the creature in this text, but this does not mean that lon itself should be understood as meaning 'demon' in this phrase. Borsje points out that she initially took lon in the Reicne as referring to a demon, stating that '[a] dangerous demon, laughing at dead people would supply a nice parallel with the terrifying Morrígain, laughing at living people.' She decides against this reading in the end, due to the fact that lon only appears to mean 'demon' in the phrase lon craís. Borsje takes lon in the poem as the 'biological species', and, given that the blackbird's song heralds the dawn, argues that the coming day is the cause of Fothad's fading presence. ${ }^{113}$

It is important to remember that names for animals and birds, in the absence of scientific taxonomies, are often imprecise. In a study of medieval Irish ornithological terms, Maria Tymoczko notes that lon glosses merula ('blackbird') in the Carlsruhe Glosses, but argues that lon is also used more generally, serving 'as a higher-order classifier'. ${ }^{114}$ Observing that lon, 'like bran and badb is used as a man's name and as a term to refer to chieftains', Tymoczko argues that

[s] uch heroic associations for the term are anomalous if its semantic field is limited to Turdus merula; the paradox is resolved if the term in some contexts can refer to a wider range of black birds, to the Corvidae in particular. ${ }^{115}$

Tymoczko draws connections between the lon craís, the fennóca ('scald-crows') that are associated with bansigaidhe in a glossary explaining passages from Bretha Nemed Dédenach, ${ }^{116}$ and the Morrígain, arguing that

[t] he avian lon craís, ... the fennóc as banshee who can prophesy death of an individual or defeat of a tribe, the war goddesses who prophesy disaster and gorge themselves on the defeated of the battle-field - all of these together form a significant mythological complex in Irish tradition of voracious consumption and devastation. ${ }^{117}$

${ }^{111}$ Kuno Meyer (ed. and trans.), Aislinge Meic Conglinne: the vision of MacConglinne, a Middle-Irish wonder tale (London, 1892), 2, 11. 9, 14, 22.

${ }^{112}$ Kenneth Hurlstone Jackson (ed.), Aislinge Meic Con Glinne (Dublin, 1990), 1, 1. 13.

${ }^{113}$ Borsje, "“Terror of the night" and the Morrígain', 91-2.

${ }^{114}$ Maria Tymoczko, 'The semantic fields of early Irish terms for black birds', in A.T.E. Matonis and Daniel F. Melia (eds). Celtic language, Celtic culture: a festschrift for Eric Hamp (Van Nuys, CA, 1990), 15171: 157 .

${ }^{115}$ Tymoczko, 'Semantic fields', 157. Tymoczko also points out that in Modern Irish cearc luin, 'female blackbird', has "negative and "ravenous" associations ... (that) indicate again an overlap in the semantic fields of the word lon and terms for the Corvidae', Tymoczko, 'Semantic fields', 158.

Gulermovich Epstein discusses the hapax enblaith, of uncertain meaning, in Aided Con Culainn ('The Death of Cú Chulainn'). Enblaith glossed lon gaile, 'black bird of valour'. This gloss combines two better known phenomena: the én gaile, 'bird of valour', and the luan laith, usually understood as 'warrior's moon' or 'warrior's light'. Gulermovich Epstein points out that while 'the accepted interpretation of lúan laith as "warrior's moon" is clear from its "standard" spelling, the first element is also written lond, lónd, lon, and lón, arguing for lon "blackbird".' Gulermovich Epstein reads this passage, in which the enblaith/lon gaile hovers over Cú Chulainn as he drives his chariot to his final battle, as possible evidence for a Celtic warrior cult, in which the Morrígain possesses a warrior and inspires a battle frenzy; see Gulermovich Epstein, 'War goddess', 237-8.

${ }^{116}$ D.A. Binchy (ed.), Corpus iuris Hibernici (6 vols, Dublin, 1978), vol. 2, 604.1. See Liam Breatnach, A companion to the Corpus iuris Hibernici, Early Irish Law Series 5 (Dublin, 2005), 28.

${ }^{117}$ Tymoczko, 'Semantic fields', 161-2. 
Returning to the Reicne, the use of the semantically flexible lon in the final verse offers interesting interpretive possibilities. While lon may be operating here simply as a term for a blackbird, the fact that its semantic range can extend to include war-like, savage connotations suggests that the poet had these in mind, given the macabre aspects that are so prominent in the text. Lon, then, may have been used here because its meaning slips between the benign and the malignant.

Borsje observes that the blackbird's vocalisation

is melodious and melancholic, but does not resemble laughter. We should, therefore, see the laughter in the poem symbolically, and it could help to combine this laughter with that of the Morrígain. People doomed to go to hell will fear the sound of the blackbird, but the faithful can enjoy it. ${ }^{118}$

While the lon's laughter may be read as a songbird joyously greeting the sunrise, oblivious to the surrounding devastation of battle, it could also be understood as the joyful cry of a greedy raven surveying a field of corpses - and indeed, the croaking call of the common raven is eerily similar to the sound of mocking human laughter. The Morrígain's strong association with carrion birds, specifically corvids, is well-known, though she is not explicitly described as a bird in the Reicne. In the Book of Leinster recension of Táin Bó Cúailnge, the Morrígain is described as perching on a coirthe ('pillar-stone') in the form of a bird. ${ }^{119}$ The account of Cú Chulainn's death in the tale Brislech Mór Maige Muirthemni is also relevant here. The hero, mortally wounded, ties himself to a pillar so that he can die standing. Watchers realise that Cú Chulainn is dead when a scald-crow (ennach) alights on his shoulder. Given the Morrígain's prominence in this text, it is nearly certain that it is she in bird-form who perches on the dead hero. ${ }^{120}$ Rather than adopt Borsje's rejected reading, in which the blackbird is a figure parallel to the Morrígain, I would argue that in the Reicne the blackbird and the Morrígain overlap, or at least that the poet intended for the audience to recall the frequent depiction of the Morrígain as a raven in medieval Irish texts, though I would not go quite so far as to claim that the lon in this verse is the Morrígain in avian form. Given the poet's tendencies to elide the divisions between the mortal woman and the battle-goddess and to play with levels of meaning, a reading whereby the blackbird and the Morrígain overlap would fit the logic of the poem. This interpretation permits us to accept Borsje's reading of the bird as a 'biological' bird, but also to stay sensitive to the nuances of the poem's intricate use of allusion and its careful patterning of certain phrases and images.

Fothad claims that it was the Morrígain who incited them (isi cotanasoíde), ${ }^{121}$ indicating that the Morrígain played the role of inciter either before or during the battle, a characterisation that is consistent with her portrayal in other texts. Ailill's wife could also be described as having incited the battle, by eloping with Fothad. The Táin contains numerous references to the Morrígain, the Badb, and related figures such as Nemain and Bé Néit inciting warriors to battle and prophesying about war. ${ }^{122}$ Within the Reicne the Morrígain

${ }^{118}$ Borsje, "'Terror of the night" and the Morrígain', 92.

${ }^{119}$ Cecile O'Rahilly (ed. and trans.), TBC LL, 1. 1304. In the same scene in the first recension of the Táin the Morrígain is first named 'Allechtu', a clear reference to the Greek Fury Allecto; see TBC 1, 1. 955. For discussion of the reference to Allecto, see Brent Miles, Heroic saga and classical epic in medieval Ireland (Cambridge, 2011), 148-50.

${ }^{120}$ Bettina Kimpton (ed. and trans.), The death of Cú Chulainn. A critical edition of the earliest version of Brislech Mór Maige Muirthemni, Maynooth Medieval Irish Texts 6 (Maynooth, 2009), 24, 1. 381.

${ }^{121}$ Meyer, Reicne, v. 42.

${ }^{122}$ See Jaqueline Borsje, 'Omens, ordeals, and oracles: on demons and weapons in early Irish texts', Peritia 13 (1999), 224-48: 238-42. 
does not speak; her only vocalisation consists of laughter. This draws the Morrígain farther away from the realm of the human and towards that of the animal: like a beast, she may make noise, but she does not speak. Like the Morrígain, Fothad's lover is speechless, a silence that is emphasised by Fothad's enjoining his lover to silence in the first and final lines of the poem: he retains sole control over the highly wrought phrases that shape meaning in the Reicne.

\section{AFTERLIVES}

Fothad's fragmented body reflects the dissolution of his identity as warrior and leader. No longer a man of action, Fothad is now literally 'all talk'. As Nagy frames it, the poem 'highlights the potentially deadly alternation between the freedom to signify and interpret signs (as in taking another's mate as one's own) and being reduced to a sign in the hands of others' ${ }^{123}$ Fothad's head is carried by a woman, whom he had wanted to claim for himself: the would-be possessor has become the possession. What had formerly been a masculine world in which men competed for women's bodies has become a feminine sphere in which Fothad's fragments - his body, his head, his viscera - are contested by women, mortal and supernatural, who will determine his fate. The Morrígain's presence on the battlefield calls forth the fear of dissolution, of being broken up and devoured as carrion.

Homosocial warrior groups are by nature masculine and exclusionary social institutions; in literature, female figures are often introduced into this world either to internally reinforce bonds between men, by acting as a social conduit between lord and follower, or as hostile, external forces that threaten the cohesion of the group, and thus reinforce it from without. ${ }^{124}$ That such a group might idealise an afterlife that is similarly homosocial is to be expected. ${ }^{125}$ Fothad departs this world at dawn, following his warriors who have gone $i$ nhuire adba ('into the abode of clay'), ${ }^{126}$ that is to say, the grave. Fothad must in some sense generate his own rebirth after death in a manner that circumvents and evades the female figures whose sexuality and devouring appetites have separated him from, and might prevent him from reuniting with, his fallen warriors. In verse 46, Fothad claims:

Imusráidhfi neach nach ré reicne Fotha[i]d Canainne, mo $c[h]$ obrad frit ni hingloe má imráite mo thimna. ${ }^{127}$

${ }^{123}$ Nagy, Conversing with angels and ancients, 302.

${ }^{124}$ For a discussion of misogyny in Germanic warrior groups, see Joseph Harris, 'Love and death in the Männerbund: an essay with special reference to the Bjarkamál and The Battle of Maldon', in Helen Damico and John Leyerle (eds), Heroic poetry in the Anglo-Saxon period: studies in honor of Jess B. Bessinger, Jr. (Kalamazoo, 1993), 77-114.

${ }^{125}$ The numerous accounts of medieval Irish otherworldly locations, sometimes portrayed as Tír inna mBan ('the Land of Women'), attest to differing conceptualisations of existence beyond the mortal world. While not 'afterlives' per se, these locations function in a manner similar to an afterlife in many texts, and it would not be controversial to posit a connection between the two on some level. The prominence of the otherworld in Acallam na Senórach, alongside its strong appeal for the Fenian warriors in that text, indicates that in Fenian tradition the fian and a 'feminine' otherworld/afterlife were not diametrically opposed, at least not by the time Acallam na Senórach was composed. That noted, Fothad does not speak longingly of Tír inna mBan. This omission on the part of the poet may be deliberate: given Fothad's antipathy towards his lover and the Morrígain, an afterlife replete with sexually desirable supernatural women presumably would not be attractive.

${ }^{126}$ Meyer, Reicne, v. 8.

${ }^{127}$ See Nagy, Conversing with angels and ancients, 300-02, for discussion of chobrad in this text. Ingle may also mean 'impure' or 'unclean', so perhaps Fothad is also telling the woman that the act of 
'Some one will at all times remember the reicne of Fothad Canainne; my discourse with thee shall not be unrenowned, if thou consider my bequest. ${ }^{, 128}$

In the following verse, he envisions a resting place for himself that will be frequently visited, and commands his lover to build him a conspicuous tomb. In this context one might view Ailill's wife as a mother figure: impregnated with Fothad's Reicne as the outcome of their tryst, she will bear his poem to the world.

In the penultimate verse, Fothad turns to Donn and the Christian God:

\section{Scarfid frit céin mo chorp toll, m'anum do pienadh la donn, \\ Serc bethu cé is miri, ingi adradh Rígh nimhi. ${ }^{129}$}

'My riddled body must part from thee awhile, My soul to be tortured by the black demon. Save (for) the worship of Heaven's King, Love of this world is folly., ${ }^{, 130}$

The invocation of the Christian God here is incongruous, as the text is set centuries before the coming of Christianity to Ireland. Here a competing, anachronistic discourse intrudes on the integrity of the narrative. There is, however, precedent for putting Christian revelation in the mouths of pre-Christian figures in medieval Irish texts: compare Finn's revelation of Christ and the arrival of St Patrick in Acallam na Senórach, or Conchobor's knowledge of Christ's birth and death, centuries before Christianity came to Ireland's shores. ${ }^{131}$ The location of Fothad's final battle is significant in this regard: as mentioned above, Linn Féic is known as one of the locations where his rival Finn receives imbas by consuming the salmon of knowledge. Fothad's revelation of the Christian God parallels Finn's reception of poetic inspiration, and Fothad's extemporaneous composition and recitation of his Reicne is also evocative of divine inspiration. Whereas Fothad negotiates his rebirth in the afterlife at Linn Féic, Finn also experiences a rebirth at Linn Féic, as a poet with a new name: formerly known as Demne, he takes the name of the poet Finn. ${ }^{132}$ There are other similarities: both Fothad and Finn come to Linn Féic for a meeting, Fothad to tryst with his lover, and Finn to learn poetry from Finnéces the poet. Linn Féic functions as an important setting for rites of passage in Fenian tradition.

Who is the 'Donn' to whom Fothad refers? When not a proper noun, donn is a colour term whose primary meaning is 'dun, brown, apparently a light brown inclining to yellow or red', but it was also used as a name for a pre-Christian Irish death god, and could also refer to the 'Christian Devil. ${ }^{133}$ Meyer originally understood donn in this passage as referring to a 'black demon', but later preferred to take donn as a reference to Donn, the pre-Christian

commemoration will cleanse her of any pollution she has incurred by speaking with the dead; see DIL, s.v. inglé.

${ }^{128}$ Meyer, Reicne, v. 46.

${ }^{129}$ Meyer, Reicne, v. 48.

${ }^{130}$ Meyer, Reicne, 17.

${ }^{131}$ Acallamh na Senórach, Stokes, 11 5414-19. Chantal Kobel, A critical edition of Aided Chonchobair 'The violent death of Conchobar': with translation, textual notes and bibliography. Unpublished PhD thesis, Trinity College Dublin (2015), 221; see also 346, 378-9. For an edition, translation, and discussion of the poem in Aided Chonchobair, see Johan Corthals, 'The Retoiric in Aided Chonchobuir', Ériu 40 (1989), 41-59.

${ }^{132}$ Kuno Meyer (ed.), 'Macgnimartha Find', RC 5 (1881-83), 195-204: 201-202.

${ }^{133}$ DIL, s.v. 1 donn; Donn. 
deity. ${ }^{134}$ Lebor Gabála Érenn describes how Donn, one of the Sons of Míl, drowns and is buried on an island, which afterward is known as Tech Duinn ('the House of Donn'). ${ }^{135}$ According to some sources, this island is where the pre-Christian Irish dwelled after death. ${ }^{136}$ One of the earliest explicit attestations of the House of Donn as the land of the dead is found in Togail Bruidne Da Derga, in a reference to setting out in the morning do thig Duind ${ }^{137}$ ('to the House of Donn'). Airne Fingein refers to travelling co Tech Duind frisndálait mairb ${ }^{138}$ ('to the House of Donn where the dead assemble'). Given that Fothad is linked to Caillech Bérri in some sources, it may be mentioned in passing that Meyer proposed that the placename Áth Alma in verse 16 of 'The lament of the old woman of Beare' is a reference to Moyalla, a river on the Beara peninsula near Dursey Island and the smaller Bull Island, the traditional location of Tech Duinn. ${ }^{139}$ The verse reads: Is éol dam a ndo-ngniat / rait ocus dorraat; / curchasa Atha Alma, is fúar in adba i faat ('I know what they are doing, / they row and row / the reeds of the Ford of Alma/ Cold is the house where they pass the night'). ${ }^{140}$ Meyer's interpretation of the lines and the identification of Áth Alma have not, however, been universally accepted.

In verse 8 , Fothad laments that his dead warriors 'go into the abode of clay' ( $a$ techt $i$ nhuire $a d b a) .{ }^{141}$ The communal grave-mound in which Fothad and his lover converse fits well with description of the 'house of clay' in which Fothad envisions the other fian-warriors residing. Considering the poem's deep investment in figures from pre-Christian Irish tradition, I take the name Donn in verse 48 as a reference to the death deity; given Fothad's fear of pianad ('punishment' or 'torture') at Donn's hands, however, the conceptualisation of Donn appears to be conflated or hybridised with Christian ideas of hell and the Devil. Donn takes on a particularly malevolent aspect here, one that is largely absent from other texts.

The Reicne contrasts the horrific physicality of the corpse-Fothad's severed head in the hands of his lover and his entrails prey to the Morrígain-with a more enduring, static afterlife, either in an ancestral, communal resting place, or the Christian heaven. Fothad is still in the liminal stage of death, with his bones still confined within his flesh, at which point the dead were viewed as most threatening to the living, in medieval Europe and elsewhere. The contact between the female figures and Fothad's corpse can also be contextualised in relation to the cross-cultural tendency to associate women with the pollution of death. In

\footnotetext{
${ }^{134}$ Kuno Meyer, 'Der irische Totengott und die Toteninsel', Sitzungsberichte der preussisches Akademie der Wissenschaften 32 (1919), 537-46: 542.

${ }^{135}$ Lebor Gábala Érenn: the book of the taking of Ireland, part 5, ed. and trans. R.A. Stewart Macalister, ITS 44 (Dublin, 1942), 38.

${ }^{136}$ Donn's role and myth is analogous to, and possibly cognate with, other Indo-European myths of the first man to die, who consequently becomes the ruler of the afterlife. Bruce Lincoln has persuasively argued that this Donn, and that other famous Donn, the Donn Cúalnge, the bull pursued by Medb in the Táin, both reflect a myth wherein one brother sacrifices another as an act of world creation, and the sacrificed brother then becomes ruler of the realm of the dead; see Bruce Lincoln, 'The lord of the dead', History of Religions 20 (1981), 22441: 227-30. See also Bruce Lincoln, Priests, warriors, and cattle: a study in the ecology of religions (Berkeley and Los Angeles, 1980), 87-90. More recently, John Carey has argued that the presence of Donn and his brother Amairgen in the Middle Irish Lebor Gabála are a reflex of 'ancient origin myths with significant analogues elsewhere in Indo-European tradition'., see John Carey, 'Donn, Amairgen, Íth, and the prehistory of Irish pseudohistory', Journal of Indo-European Studies 38 (2010), 319-41: 318.

${ }^{137}$ Eleanor Knott (ed.), Togail Bruidne Da Derga, MMIS 8 (Dublin, 1936), 22.

${ }^{138}$ Airne Fíngein, ed. Joseph Vendryes (Dublin, 1975), 20.

${ }^{139}$ Meyer, 'Der irische Totengott', 543-4.

${ }^{140}$ Ó hAodha, 'The lament of the old woman of Beare', 312, 324, v. 16.

${ }^{141}$ Meyer, Reicne, v. 8. While the 'abode of clay' may be a simple metaphor for the grave, it bears a close resemblance to the 'house of clay' that Bruce Lincoln has analysed as an Indo-European conceptualisation of the afterlife, and which he specifically relates to a ninth-century description of Tech nDuinn; see Bruce Lincoln, Death, war, and sacrifice: studies in ideology and practice (Chicago, 1991), 112-13.
} 
addition to the ritual of washing and preparing the corpse for burial and the "Washer at the Ford' topos, the motif of keening women drinking the blood of the dead in Irish poetry also positions women as consumers of pollution. ${ }^{142}$ The Reicne offers both 'positive' and 'negative' depictions of the association between women and pollution: Ailill's wife carries the severed head of her lover into the grave and strips the dead of their belongings, while the Morrígain, with her laughter and tossing hair, delights in gore as she washes the entrails of the slain. Fothad must avoid being entrapped by feminine forces in the nocturnal world of the grave and the battlefield, which are contrasted with the kingdom of Heaven and the House of Donn, a community of ancestors. This gendered dichotomy recalls a funerary ritual among the Bara of Madagascar that has been analysed by Bloch and Parry. Upon death, two sexsegregated huts are set aside, and the corpse is secluded in the women's hut for three nights and two days. After this period the men take the corpse away from the women's hut by force, and the young men carry the coffin at a run to the ancestral tomb, hindered along the way by young women. According the Bloch and Parry,

All this suggests a ritual drama in which women are given the role of an unacceptable obscene sexuality, in which they deliberately endeavour to implicate men, which takes place at night and which must be broken through during the day ... in order to attain proper rebirth into the world of the ancestors. In other words, it is the necessary defeat of women, sexuality and biology which is enacted, rather than their indispensable part in the recreation of life. ${ }^{143}$

\section{(RE)BIRTH}

My discussion thus far has focused on the Old Irish texts, but some details in the Middle Irish prose narrative suggest that the Middle Irish redactor may have also been interested in some of the themes outlined above, and shaped his account to resonate with them. I will limit myself to a single, striking correspondence between the Middle Irish prose narrative and the Reicne: both Fothad's biological birth and his 'rebirth' into the afterlife take place over the course of a single night, and in both instances he is preceded by close male companions. He is a triplet: D'óentoirpirt ructha iat a triur la Fuinche ingin Náir ('At one birth they were all three brought forth by Fuinche, daughter of Nár'). ${ }^{144}$ Fuinche's labour lasted from dusk until dawn:

Breatha Fuinche Aendia i tús aidchi; is de isberar ainm dó, ar ba gein ríg ar febus in thseóin. Tréndia a medón aidche. Is de dobreath ainm dó ar treissi in thseóin lasna déib and. Cáendia issin maidin; ar caíme 7 ar áille na fungaire na maidne 7 is aire is Cáendia a ainm.

'Fuinche brought forth Oendia at nightfall. He is so called, because he was a king's son, for the excellence of the lucky hour. Tréndia was born at midnight. The name

${ }^{142}$ I thank Danielle Cudmore for this observation. For a discussion of the motif of blood drinking during keening, see: Alexandra Bergholm, 'The drinking of blood in the ritual context of mourning', in Anders Ahlqvist and Pamela O'Neill (eds), Language and power in the Celtic world: papers from the seventh annual Australian Conference of Celtic Studies, Sydney Series in Celtic Studies 10 (Sydney, 2011), 1-12; and Simon Rodway, 'Affectionate cannibalism and the blood drinking motif in Gaelic literature', CMCS 74 (2017), 47-65. See also Salvador Ryan, 'Popular religion in Gaelic Ireland, 1445-1645' (2 vols). Unpublished PhD thesis, National University of Ireland, Maynooth (2002), 2: 172-9.

${ }^{143}$ Bloch and Parry, 'Introduction', 21.

${ }^{144}$ Meyer, Reicne, 4. 
was given to him for the strength of luck with the gods at that hour. Cáindia (was born) in the morning. Because of the loveliness and the beauty of the dawn of morning, therefore Cáindia is his name., 145

The Middle Irish introduction devotes considerable space to the names of the three brothers, who are, as Nagy observes, 'overmarked with a superfluity of names' that 'strengthen the collective identity among them': ${ }^{146}$

Is de asbertha na Fothaig friu .i. fotha-suith iat, ar isí cétchlann ruc Fuinche iat do Macnia. Nó Fothad .i. fó-táide .i. fo clith dorónad la Mac Niath iat fri Fuinche ingin Náir maic Armara. Nó Fothad .i. fi-áeda .i. olc-teine .i. teine neimneach iat ic orcain clann 7 cinél. Aendia immurro 7 Tréndia 7 Cáendia a n- anmanna. Aendia in tAirgteach, Tréndia in Cairptech, Cáendia Fothad Canann.

'This was why they were called the Fothads, because they were fotha suith, 'a foundation of offspring'; for they were the first children whom Fuinche bore to Macnia. Or Fothad, viz., fo-táide, i.e. by stealth were they begotten by Macnia upon Fuinche the daughter of Nár son of Armair. Or, Fothad, viz., fi-áeda, i.e. venom of fire, for they were a virulent fire in destroying clans and races. Oendia ('one god'), however, and Tréndia ('strong god') and Cáindia ('fair god') were their names. Oendia was Airctech, Tréndia was Cairptech, Cáindia was Fothad Canann., 147

Three etymologies are given for Fothad, the name shared by the three brothers. The derivation of Fothad from fo-táide, from the noun táide 'stealth, secrecy; secret and hence illicit intercourse, fornication, adultery', ${ }^{148}$ anticipates Fothad's seduction of Ailill's wife. The etymology from ' $f i$-áeda, i.e.. venom of fire, for they were a virulent fire in destroying clans and races', foreshadows the mutual destruction of the two fiana that is the subject of the text. The eldest Fothad, Fothad Airctech, was named for his love of wealth, a trait that is evidenced by Caílte's account of his burial in Scél asa mberar combad hé Find mac Cumaill Mongán. ${ }^{149}$ The middle brother is Fothad Cairptech 'of the Chariots', so named because he would gift his sons with chariots and horses. The byname of Fothad Canainne is given two explanations: he is either 'called from Canann, a hound that he had' (is de isberar .i. ó Canaind, ón choin robói aicce), or he is 'Fothad Cáinine, viz. caín, i.e. delightful was the day when he was born' (Fothad Caenine .i. cain .i. álaind in dee intan nodrucad). ${ }^{150}$ The bynames given to the three Fothads are indicative of a shared masculine identity: hounds,

${ }^{145}$ Meyer, Reicne, 4-5. On the use of dia 'god' in the brothers' names, see John Carey, 'Dee "pagan deity"', Ériu 62 (2012) 33-42, at 37, fn. 22.

${ }^{146} \mathrm{Nagy}$, Conversing with angels and ancients, 299.

${ }^{147}$ Meyer, Reicne, 4.

${ }^{148}$ DIL, s.v. táide.

${ }^{149}$ A:tá comrar chloiche imbi and hi talam. A:taat a di foil airgit ocus a da buinne doat ocus a muintorc argit fora chomrair ('There is a coffin of stone around him there in the ground. There are his two rings of silver and his two armlets and his torc of silver upon his coffin'), see Nora White (ed. and trans.), Compert Mongáin and three other early Mongán tales: a critical edition with introduction, translation, textual notes, bibliography and vocabulary, Maynooth Medieval Irish Texts 5 (Maynooth, 2006), 74, 81, §14. Mongán, a king, has disagreed with a poet's account of the death of Fothad Airctech, prompting the poet to threaten to satirise Mongán. The king and the poet eventually agree that unless Mongán can prove the poet wrong, the poet will claim Mongán's wife. She is spared by Caílte, Finn's close companion, who arrives at the last minute to describe the burial of Fothad Airctech. The grave is investigated, and Mongán's claim is proved against the poet. During this visit, Caílte heavily implies that Mongán is the reincarnation of Finn mac Cumaill.

${ }^{150}$ Meyer, Reicne, 6. 
chariots, and fine adornments are the possessions of a warrior aristocracy. Furthermore, Fothad's byname connects him to the pervasive canine associations of the fian. ${ }^{151}$ The circumstances and description of Fothad's birth align him more strongly with his brothers and a male world of hunting, war and material wealth than with his mother. The image of the three brothers confined within a single womb recalls not only the fert into which Fothad, and presumably the other fallen warriors, must go, but also the ferbolg containing the fidchellpieces that Fothad gives to Ailill's wife - both are bag-like containers, 'possessed' by a woman, that enclose and conceal a miniature company of 'warriors'-future warriors in the case of the three Fothads, and symbolic warriors in the case of the fidchell-men.

A tendency on the part of some medieval Irish authors to diminish women's roles in sexual reproduction, a predilection that may have arisen from a desire to limit and control women's reproductive power, has been remarked upon. ${ }^{152}$ One might argue that these authors, attempting to alleviate the anxiety of acknowledging the importance of the mother, systematically excised women from the processes of conception and parturition. The reliance of a warrior society on women's reproductive roles may be obscured in the textual record, but anxiety about this dependence manifests nonetheless. Even as the Middle Irish prose introduces Fothad's mother into the narrative, her role in his birth is minimised: emphasis is placed on the other two Fothads with whom he shares the womb, gesturing towards his eventual role as the leader of a fian. There is some evidence for processes of reproductive substitution in a Fenian context elsewhere in the corpus. John Carey has argued that a pagan Irish ritual of fealty engages in the erasure of women's reproductive roles:

anxieties ... may also be reflected in strategies for avoiding women entirely. There are traces of an ancient Irish custom whereby one man indicated his fealty to another by sucking the latter's nipples. Here, in a male group in which the leader is symbolically regarded as 'mother', a ritual reality is created in which women - with all the dangers which they pose for warriors - are no longer necessary. ${ }^{153}$

Carey observes that

both of the primary items of evidence for this behaviour are associated with water. When Patrick was escaping from slavery in Ireland, the men with whom he was seeking to take ship expected him 'to suck their breasts' (sugere mammellas eorum) ... And in the Old Irish account of his adventures, the warrior king Fergus mac Léti is said to have received submission in this form from a diminutive water-spirit. ${ }^{154}$

Carey points out that James Carney has proposed that the sailors who ask Patrick to engage in this ritual were 'a band of roving adventurers, otherwise a fian ... and admission to whose company involved the Irish pagan rite of breast-sucking'. ${ }^{155}$ The matter requires more

${ }^{151}$ McCone, 'Werewolves, cyclopes, Díberga and Fíanna', passim.

${ }^{152}$ See Maeve B. Callan, 'Of vanishing fetuses and maidens made-again: abortion, restored virginity, and similar scenarios in medieval Irish hagiography and penitentials', Journal of the History of Sexuality 21 (2012): 282-96: 287, 288, and 291-2; Lisa Bitel, The land of women (Ithaca, 1996), 81-3.

${ }^{153}$ John Carey, 'The encounter at the ford: warriors, water, and women', Éigse 34 (2004 ), 10-24: 23. For a discussion of this motif in a cross-cultural context, see also Bernhard Maier, 'Sugere mammellas: a pagan Irish custom and its affinities', in Ronald Black, William Gillies and Roibeard Ó Maolalaig (eds), Celtic connections: proceedings of the tenth International Congress of Celtic Studies, vol. 1: Language, literature, history, culture (East Linton, 1999), 152-61.

${ }^{154}$ Carey, 'Encounter at the ford', 23.

155 James Carney, The problem of St. Patrick (Dublin, 1973), 67. 
investigation, but the manner in which the Middle Irish prose text crafts the account of Fothad's birth to parallel that of his death while eliding the role of his mother is intriguing. It may be compared with the tendency, described by Bloch, for the collapsing of 'biological birth and biological death' into a single category that is associated with women, and its symbolic opposition to rites of 'socio-moral birth' and 'social death' that are carried out by men in some cultures. ${ }^{156}$

\section{Conclusion: The Centre Cannot Hold}

Reicne Fothaid Canainne and the Old Irish and Middle Irish prose texts present relationships between men and women as disruptive not only to the social order, but also to the boundaries between life and death. The connection between erotic desire and death is reinforced throughout the poem. Unlike Brân in the Second Branch of the Mabinogi, whose massive head presides over a supernatural feast for his warriors and serves as a protector of the island of Britain after death, ${ }^{157}$ or Anlúan in Scéla Mucce Meic Da Thó, whose severed head offers proof of prowess in a verbal contest between warriors, ${ }^{158}$ Fothad's head is in the hands of a woman. With both fiana dead to the last man, Fothad has neither followers nor enemies who could use his severed head in negotiations of masculine authority. In the absence of other men, Fothad must negotiate his identity through rejection of the feminine which he had formerly attempted to co-opt for himself. The impossibility of fully enacting that rejection is made clear in his reliance on his living lover to inherit his wealth, remember the Reicne, and construct his tomb.

The instability attendant upon Fothad's situation is deeply ironic, given that the first etymology given for his name in the Middle Irish prose text is fotha, 'foundation'. ${ }^{159} \mathrm{We}$ might detect another stratum of irony if we look to the noun foth, 'claim, right, title, property', but also 'a thing which someone else has a claim on, which has been promised to someone else, or is forfeit to someone else. ${ }^{, 160}$ The text is deeply concerned with the transfer and loss of ownership - of Ailill's wife, of Fothad's treasures and those of his retinue, and of Fothad's own corpse. As the sun rises, Fothad's ability to ward off the reality-and finalityof death weakens. Though his lover remains silent while he declaims the Reicne, in the final verses the lon's laughter intrudes, heralding his failure. Fothad's turn towards the Christian God comes too late: unlike so many of the pre-Christian heroes who achieve posthumous salvation in Irish literature, Fothad's revelation does not save him. The poem concludes with the haunting call of the lon, the laughter of the dark-winged bird recalling that of the Morrígain, an aural reminder of the death, loss and dissolution of the fian.

\footnotetext{
${ }^{156}$ Bloch, 'Death, women and power', 220.

157 Thomson, Branwen uerch Lyr, 16-17.

${ }^{158}$ Rudolf Thurneysen (ed.), Scéla Mucce Meic Dathó (Dublin, 1935; repr. 1951).

${ }^{159}$ DIL, s.v. fotha.

${ }^{160}$ DIL, s.v. foth.
} 